\title{
ESTIMATES OF GROUND-WATER RECHARGE RATES FOR TWO SMALL BASINS IN CENTRAL NEVADA
}

\section{by Robert W. Lichty and Patrick W. McKinley}

\section{U.S. GEOLOGICAL SURVEY}

Water-Resources Investigations Report 94-4104

Prepared in cooperation with the

NEVADA OPERATIONS OFFICE,

\section{U.S. DEPARTMENT OF ENERGY under}

Interagency Agreement DE-Al08-92NV10874

\section{DISCLAIMER}

This report was prepared as an account of work sponsored by an agency of the United States Government. Neither the United States Government nor any agency thereof, nor any of their employees, makes any warranty, express or implied, or assumes any legal liability or responsibility for the accuracy, completeness, or usefulness of any information, apparatus, product, or process disclosed, or represents that its use would not infringe privately owned rights. Reference herein to any specific commercial product, process, or service by trade name, trademark, manufacturer, or otherwise does not necessarily constitute or imply its endorsement, recommendation, or favoring by the United States Government or any agency thereof. The views and opinions of authors expressed herein do not necessarily state or reflect those of the United States Government or any agency thereof.

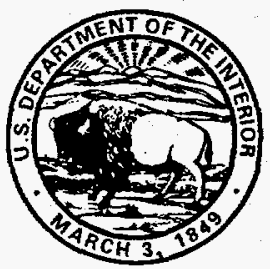




\section{U.S. DEPARTMENT OF THE INTERIOR \\ BRUCE BABBITT, Secretary}

U.S. GEOLOGICAL SURVEY

Gordon P. Eaton, Director

The use of trade, product, industry, or firm names is for descriptive purposes only and does not imply endorsement by the U.S. Government.

For additional information write to: Chief, Earth Science Investigations Program

Yucca Mountain Project Branch U.S. Geological Survey

Box 25046, MS 421

Denver Federal Center

Denver, CO 80225
Copies of this report can be purchased from: U.S. Geological Survey Earth Science Information Center Open-File Reports Section Box 25286, MS 517 Denver Federal Center Denver, CO 80225 


\section{DISCLAIMER}

Portions of this document may be illegible in electronic image products. Images are produced from the best available original document. 


\section{CONTENTS}

Abstract

Introduction

Description of the study areas

Description of models

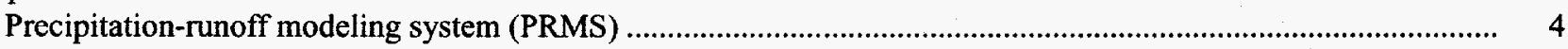

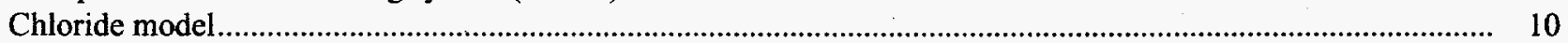

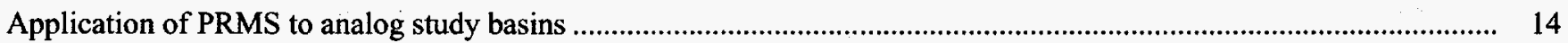

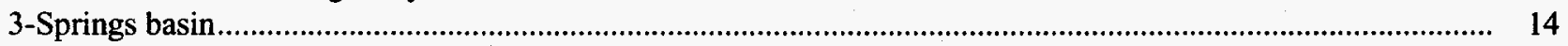

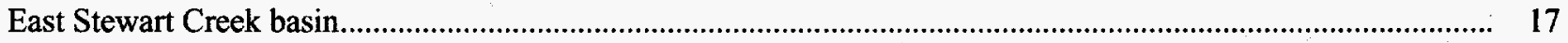

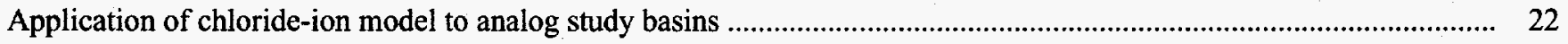

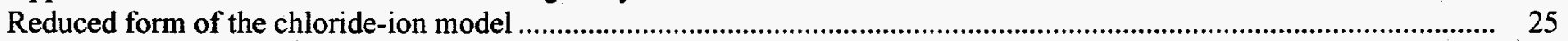

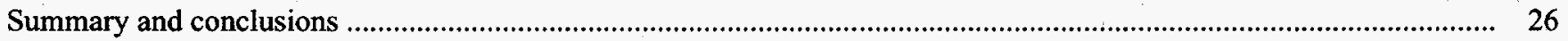

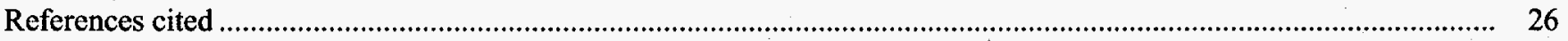

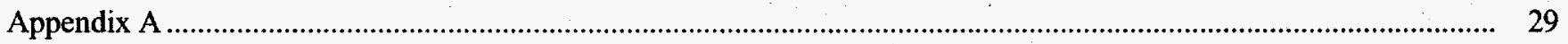

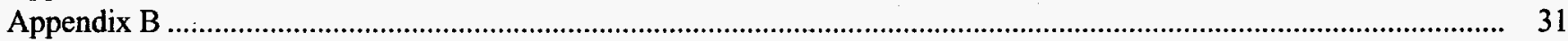

\section{FIGURES}

1. Map showing locations of the study areas in Nevada ...............................................................................

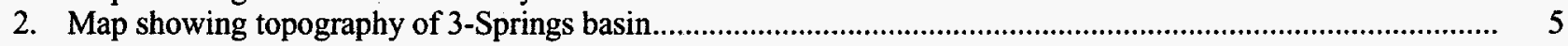

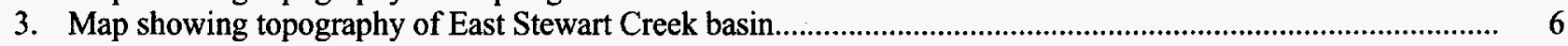

4. Schematic diagram of the conceptual watershed system and its input.............................................................. 7

5. Diagram of components of the snowpack energy-balance equations................................................................... 8

6. Graph showing effect of tree-canopy density on snow interception ............................................................. 12

7. Graph showing functional relations between winter forest-cover density (COVDNW) and the transmission coefficient (TRNCF) of the forest canopy............................................................................. 13

8. Graph showing observed and simulated daily-mean discharge for water years 1987 through 1989 of 3-Springs Creek, Central Nevada.

9. Graph showing observed and simulated daily-mean discharge for water years 1990 through 1992 of

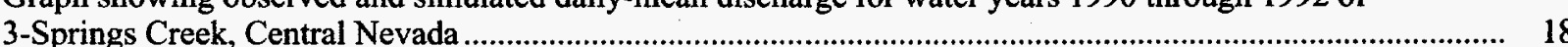

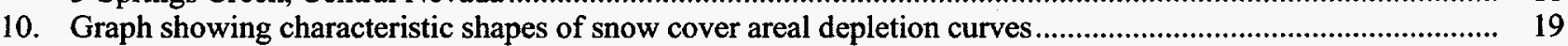

11. Graph showing observed and simulated daily-mean discharge for water years 1987 through 1989 of East Stewart Creek, Central Nevada .....

12. Graph showing observed and simulated daily-mean discharge for water years 1990 through 1992 of East Stewart Creek, Central Nevada

\section{TABLES}

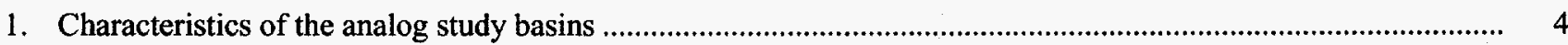

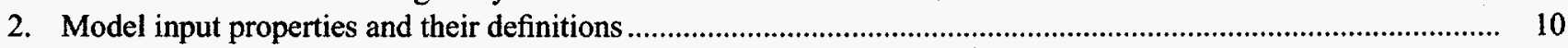

3. Sensitivity of simulated annual potential evapotranspiration demand to CTS for 3-Springs basin ....................... 15

4. Sensitivity of simulated annual runoff to SMAX for 3-Springs basin ........................................................... 16

5. Simulated and observed snowpack water equivalents for 3-Springs basin ..................................................... 16

6. Summary of simulation results for 3-Springs basin ...................................................................................... 16

7. Sensitivity of simulated annual runoff to SMAX, East Stewart Creek basin ...................................................... 19

8. Simulated and observed snowpack water equivalents, East Stewart Creek basin ................................................ 19

9. Summary of simulation results for East Stewart Creek basin.......................................................................

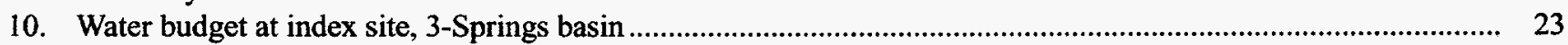

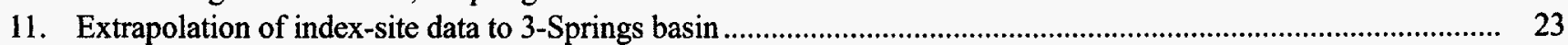

12. Water budgets at lower and upper index sites, East Stewart Creek basin ....................................................... 24

13. Extrapolation of index-site data to East Stewart Creek basin ........................................................................ 24

14. Average annual losses $\left(E_{t}+E_{s}\right)$, and available moisture $\left(R_{g}+R_{s}\right)$ for the analog study basins ......................... 25

15. Compilation of observed data and model estimates of average annual recharge for study basins ......................... 26 
CONVERSION FACTORS AND VERTICAL DATUM

\begin{tabular}{rll}
\hline Multiply & By & To obtaln \\
\hline calorie $(\mathrm{cal})$ & 4.184 & joule \\
centimeters per year $(\mathrm{cm} / \mathrm{yr})$ & & \\
cubic meter per second $\left(\mathrm{m}^{3} / \mathrm{s}\right)$ & 0.02832 & cubic foot per second \\
meter $(\mathrm{m})$ & 0.3048 & foot \\
millimeter $(\mathrm{mm})$ & 25.4 & inch \\
kilometer $(\mathrm{km})$ & 1.609 & mile \\
square kilometer $\left(\mathrm{km}^{2}\right)$ & 2.590 & square mile \\
\hline
\end{tabular}

Degree Celsius $\left({ }^{\circ} \mathrm{C}\right)$ may be converted to degree Fahrenheit $\left({ }^{\circ} \mathrm{F}\right)$ by using the following equation:

$$
{ }^{\circ} \mathrm{F}=9 / 5\left({ }^{\circ} \mathrm{C}\right)+32 \text {. }
$$

Sea level: In this report "sea level" refers to the National Geodetic Vertical Datum of 1929 (NGVD of 1929)-a geodetic datum derived from a general adjustment of the first-order level nets of both the United States and Canada, formerly called Sea Level Datum of 1929. 


\title{
Estimates of Ground-Water Recharge Rates for Two Small Basins in Central Nevada
}

\author{
By Robert W. Lichty and Patrick W. McKinley
}

\section{Abstract}

Estimates of ground-water recharge rates developed from hydrologic modeling studies are presented for 3-Springs and East Stewart basins, two small basins (analog sites) located in central Nevada. The analog-site studies were conducted to aid in the estimation of recharge to the paleohydrologic regime associated with ground water in the vicinity of Yucca Mountain under wetter climatic conditions. The two analog sites are located to the north and at higher elevations than Yucca Mountain, and the prevailing (current) climatic conditions at these sites is thought to be representative of the possible range of paleoclimatic conditions in the general area of Yucca Mountain during the Quaternary. Two independent modeling approaches were conducted at each of the analog sites using observed hydrologic data on precipitation, temperature, solar radiation, stream discharge, and chloride-ion water chemistry for a 6-year study period (October 1986 through September 1992). Both models quantify the hydrologic water-balance equation and yield estimates of ground-water recharge, given appropriate input data. The first model uses a traditional approach to quantify watershed hydrology through a precipitation-runoff modeling system that accounts for the spatial variability of hydrologic inputs, processes, and responses (outputs) using a daily computational time step. The second model is based on the conservative nature of the dissolved chloride ion in selected hydrologic environments, and its use as a natural tracer allows the computation of a coupled, water and chloride-ion, mass-balance system of equations to estimate available water (sum of surface runoff and groundwater recharge).

Results of the modeling approaches support the conclusion that reasonable estimates of average-annual recharge to ground water range from about 1 to 3 centimeters per year for 3-Springs basin (the drier site), and from about 30 to 32 centimeters per year for East Stewart basin (the wetter site). The most reliable results are those derived from a reduced form of the chloride-ion model because they reflect integrated, basinwide processes in terms of only three measured variables: precipitation amount, precipitation chemistry, and streamflow chemistry.

\section{INTRODUCTION}

The U.S. Geological Survey, in cooperation with the U.S. Department of Energy, is conducting hydrologic and geologic investigations aimed at providing information to help evaluate the suitability of Yucca Mountain as a site for development of a high-level, nuclear-waste repository. The study activities are conducted under the Yucca Mountain Project, and the results described herein relate to the analog recharge study, one of four activities of the characterization of the Yucca Mountain Quaternary Regional Hydrology project. The objective of the 1-day recharge study is to describe hydrologic conditions in the Yucca Mountain area for the Quaternary, and more specifically, for the past 20,000 years. Knowledge of the paleohydrologic ground-water regime of the Yucca Mountain area is pertinent to the assessment and evaluation of the suitability of the site for development as a high-level, nuclear-waste repository. This is because information on past hydrologic conditions at Yucca Mountain and environs is essential to the development of meaningful scenarios of future hydrologic system response to climatic changes.

The analog recharge study activity was designed to evaluate the precipitation-runoff relation; and, in particular, to quantify hydrologic water-balance components that support the determination of the magnitude of ground-water recharge rates that may have existed in the past and may possibly exist in the future. The purpose of this report is to describe the results of hydrologic modeling studies conducted using data collected at two small basins in central Nevada (fig. 1). The two analog sites are located to the north and at 


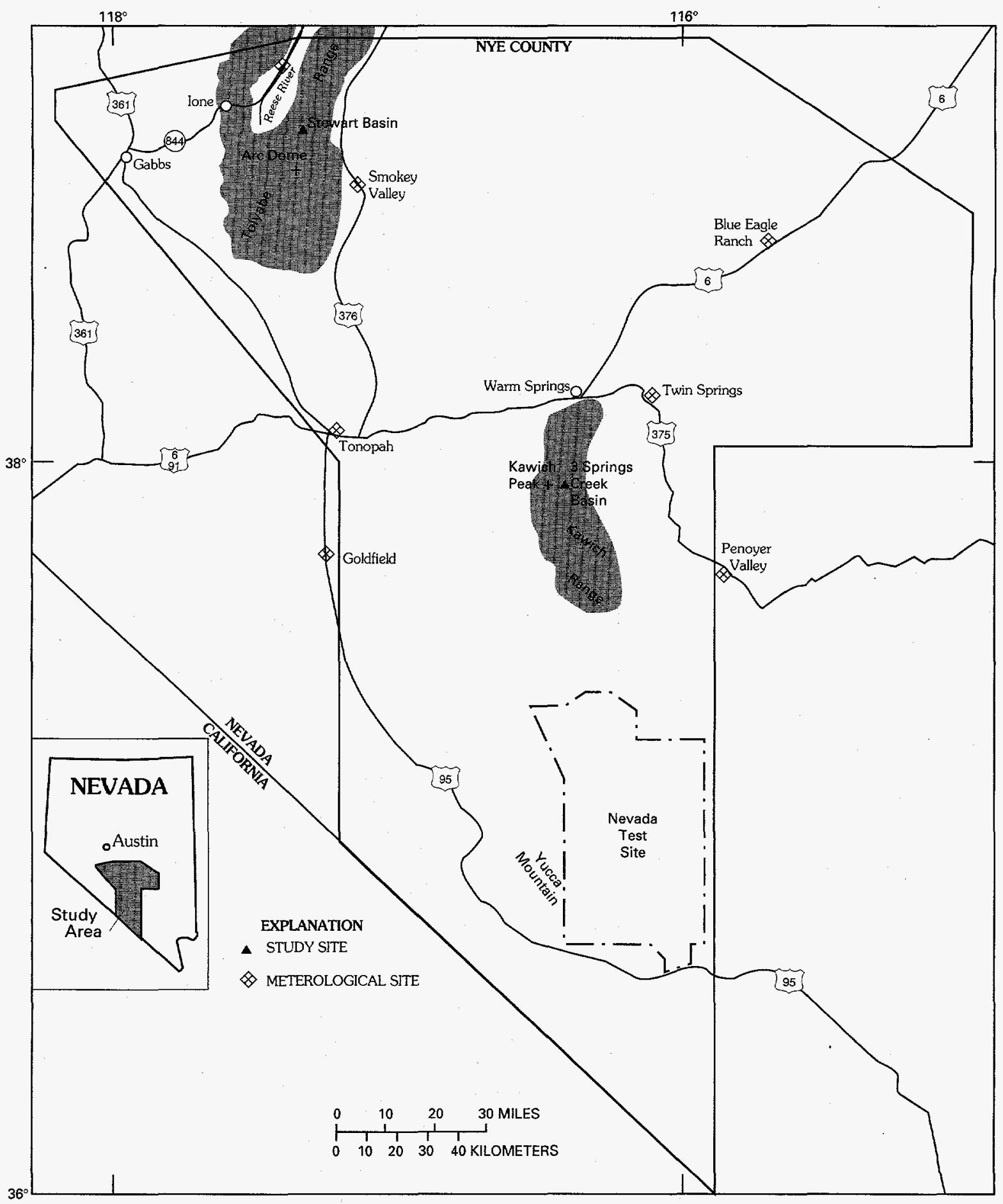

Figure 1. Locations of the study areas in Nevada. 
higher elevations than the proposed Yucca Mountain repository site. The current climatic conditions at the analog site locations are thought to be representative of the possible range of paleoclimatic conditions in the general area of the repository site during the Quaternary.

Two independent, but complementary, modeling activities were conducted at each of the analog sites. Both models quantify the hydrologic water-balance equation and yield estimates of ground-water recharge, given appropriate input data.

The first modeling activity uses a traditional approach to quantify watershed hydrology by using a precipitation-runoff modeling system (PRMS) as described by Leavesley and others (1983). PRMS accounts for the spatial variability of hydrologic inputs, processes, and responses (outputs) using a daily computational time step. In some special modeling applications, a shorter computational time step may be used such as in the flood-routing simulation mode.

The second model is predicated on the conservative nature of the dissolved chloride ion in selected hydrologic environments and its use as a natural tracer is the basis for the development of a chloride-ion, mass-balance modeling algorithm (Claassen and others, 1986). The model identifies and quantifies, through operational rules of computation, the mechanisms affecting chloride-ion concentration changes from the source of the chloride ion as a constituent of precipitation input to final disposition within the watershed as discharge (including both surface and subsurface streamflow components). The model, in its original form and application, pertains to locals that typically experience a fall through winter snowaccumulation season followed by a spring snowmelt season, as is the case for the two analog basins.

\section{DESCRIPTION OF THE STUDY AREAS}

The two analog recharge study sites are in Nye County to the north and west of Yucca Mountain (fig. 1). Physical characteristics of the study basins are listed in table 1 . Both study sites are characterized by high relief and rough terrain with elevations ranging from about 2,150 to $2,900 \mathrm{~m}$ above sea level for 3-Springs basin and from about 2,950 to $3,320 \mathrm{~m}$ for East Stewart basin.

The climate at 3-Springs basin is semiarid with annual precipitation generally in the range of 25 to $35 \mathrm{~cm}$, most of which occurs as snow during the period October through May. Annual discharge, if any, is from snowmelt feeding subsurface flow components. Overland flow in response to storm rainfall is rare. The vegetation at 3-Springs basin can be classified into three main categories: pinon-juniper woodland, moun- tain mahogany woodland, and mixed upland shrub. In addition, small areas of riparian shrub exist along some of the more moist valley bottoms. The basin is drained by several small tributaries connecting to a southeasttrending main-stem branch (fig. 2). The steep side slopes of the basin are underlain by Tertiary volcanic tuffs that are exposed in numerous bedrock outcrops. Soils are fine- to coarse textured and moderately well drained except along a few moist valley bottoms. For the purpose of hydrologic modeling, the basin area was subdivided into 50 hydrologic response units, mainly on the basis of differences in slope, aspect, elevation, and canopy cover type and density.

The reason for partitioning a basin into hydrologic response units (HRU's) is to achieve an appropriately detailed specification of important "ground-truth" hydrologic characteristics. These characteristics influence not only hydrologic processes such as interception, evapotranspiration, infiltration, and so forth, but also support a meaningful representation of the spatial variability in the so-called driving data. For example, the spatial variability in temperature, precipitation, and solar radiation can be incorporated and accounted for in the delineation of HRU's. A listing of HRU characteristics is in Appendix A.

The East Stewart Creek study site is a subalpine drainage basin located to the north of Arc Dome in the Toiyabe Range north of Tonopah (fig. 1). Annual precipitation is generally in the range of 50 to $70 \mathrm{~cm}$, most of which occurs as snow during the period October through May. Streamflow at East Stewart Creek is perennial and is dominated by subsurface flow components derived from infiltration of snowmelt water and its subsequent percolation and drainage through numerous springs and seeps. The thin soil mantle has little water-holding capacity and, therefore, the basin yields a high percentage of incident precipitation as runoff. Typically, 45 to 55 percent of annual precipitation over the basin is measured as runoff at the streamflow-gaging site (fig. 3). Overland flow in response to storm rainfall was not detected in the hydrograph trace.

The terrain is steep but less rugged than that exhibited at 3-Springs basin, with fewer tributaries to the main-stem branch, which flows in a northwesterly direction (fig. 3). The vegetation, which consists primarily of aspen, mountain mahogany, limber pine, and upland shrub, is much less dense than that in the 3-Springs basin area. The basin is underlain by volcanic tuffs of Tertiary age. Soils are poorly developed, shallow, highly permeable and well drained. The basin was subdivided into 15 HRU's on the basis of differences in slope, aspect, elevation, and canopy cover type and density. A listing of unit characteristics is in Appendix B. 
Table 1. Characteristics of the analog study basins

[ $\mathrm{km}^{2}$, square kilometer; $\mathrm{m}$, meter; deg. degree Celsius; cal $\mathrm{cm}^{-2}$, calorie per square centimeter; $\mathrm{cm}$, centimeter]

\begin{tabular}{|c|c|c|c|c|c|c|c|c|}
\hline \multirow{2}{*}{$\begin{array}{l}\text { Name and } \\
\text { location }\end{array}$} & \multirow{2}{*}{$\begin{array}{c}\text { Area } \\
\left(\mathbf{k m}^{2}\right)\end{array}$} & \multirow{2}{*}{$\begin{array}{l}\text { Median } \\
\text { altitude } \\
\text { (m) }\end{array}$} & \multicolumn{2}{|c|}{$\begin{array}{c}\text { Canopy cover } \\
\text { density in } \\
\text { percent }\end{array}$} & \multicolumn{4}{|c|}{ Mean annual* } \\
\hline & & & Trees & Shrubs & $\begin{array}{c}\text { Temperature } \\
\text { (deg) }\end{array}$ & $\begin{array}{c}\text { Solar } \\
\text { radiation } \\
\left(\text { cal } \mathrm{cm}^{-2} \text { ) }\right.\end{array}$ & $\begin{array}{l}\text { Precipitation } \\
\text { (cm) }\end{array}$ & $\begin{array}{c}\text { Runoff } \\
\text { (cm) }\end{array}$ \\
\hline 3-Springs & 4.20 & 2,500 & 30 & 8 & 7.8 & 159,600 & 33.64 & 1.07 \\
\hline North latitude & 37.96 degrees & & & & & & & \\
\hline West longitude & 116.42 degrees & & & & & & & \\
\hline East Stewart & 0.93 & 3,100 & 19 & 3 & 3.3 & 143,300 & 63.91 & 33.05 \\
\hline North latitude & 38.89 degrees & & & & & & & \\
\hline West longitude & 117.36 degrees & & & & & & & \\
\hline
\end{tabular}

\section{DESCRIPTION OF MODELS}

\section{Precipitation-Runoff Modeling System (PRMS)}

The precipitation-runoff modeling system (PRMS), is a deterministic, distributed-characteristic, watershed-modeling system that simulates the physical processes that comprise the land phase of the hydrologic cycle (Leavesley and others, 1983). The development and operation of PRMS is based on a

conceptualization of the watershed system as an interconnected series of storage elements linked by mathematical operating rules. Figure 4 is a schematic diagram of the conceptual watershed components and the driving inputs (precipitation, air temperature, solar radiation), and outputs (streamflow, evaporation, transpiration, sublimation) that are represented for a typical HRU. The HRU concept facilitates the subdivision of a watershed into areas of similar physical characteristics and allows a reasonable approximation of the spatial variability of hydrologic response. In addition, the HRU delineation can be used to characterize differences in input driving data; for example, the influence of land slope and slope aspect on incident solar radiation.

The linkages and operations of the various components depicted in figure 4 are represented mathematically by known physical laws or empirical relations developed based on measurable watershed characteris- tics. Daily values of precipitation in the form of rain, snow, or a mixture of the two is the input source of moisture to the land surface. PRMS also supports storm rainfall input defined at short time intervals; for example, 5-minute data, for applications that require kinematic flood routing of surface runoff-not a significant factor for the analog study basins addressed here. The energy inputs of daily maximum and minimum air temperature and daily total solar radiation drive the processes of evaporation, transpiration, sublimation, and snowmelt.

The model structure includes four vertically stratified components that depict a surficial component represented by vegetative canopy, transient snowcovered areas, and impervious surfaces overlying three storage-reservoir components. They are: (1) a soilzone reservoir, (2) a subsurface reservoir, and (3) a ground-water reservoir (fig. 4). The specification of an impervious-zone reservoir is used in urban environments and was not considered in the application of PRMS to the analog study basins. The operations and outputs of these components combine, on a unit area basis, to produce the simulated response of the total watershed.

Precipitation input is reduced by interception in the vegetative canopy and becomes the net precipitation at the land surface where it either accumulates as snowpack, infiltrates the soil zone, or becomes surface runoff (fig. 4). The model algorithms are structured to compute a daily water balance using values of net precipitation, adjusted maximum and minimum air tem- 


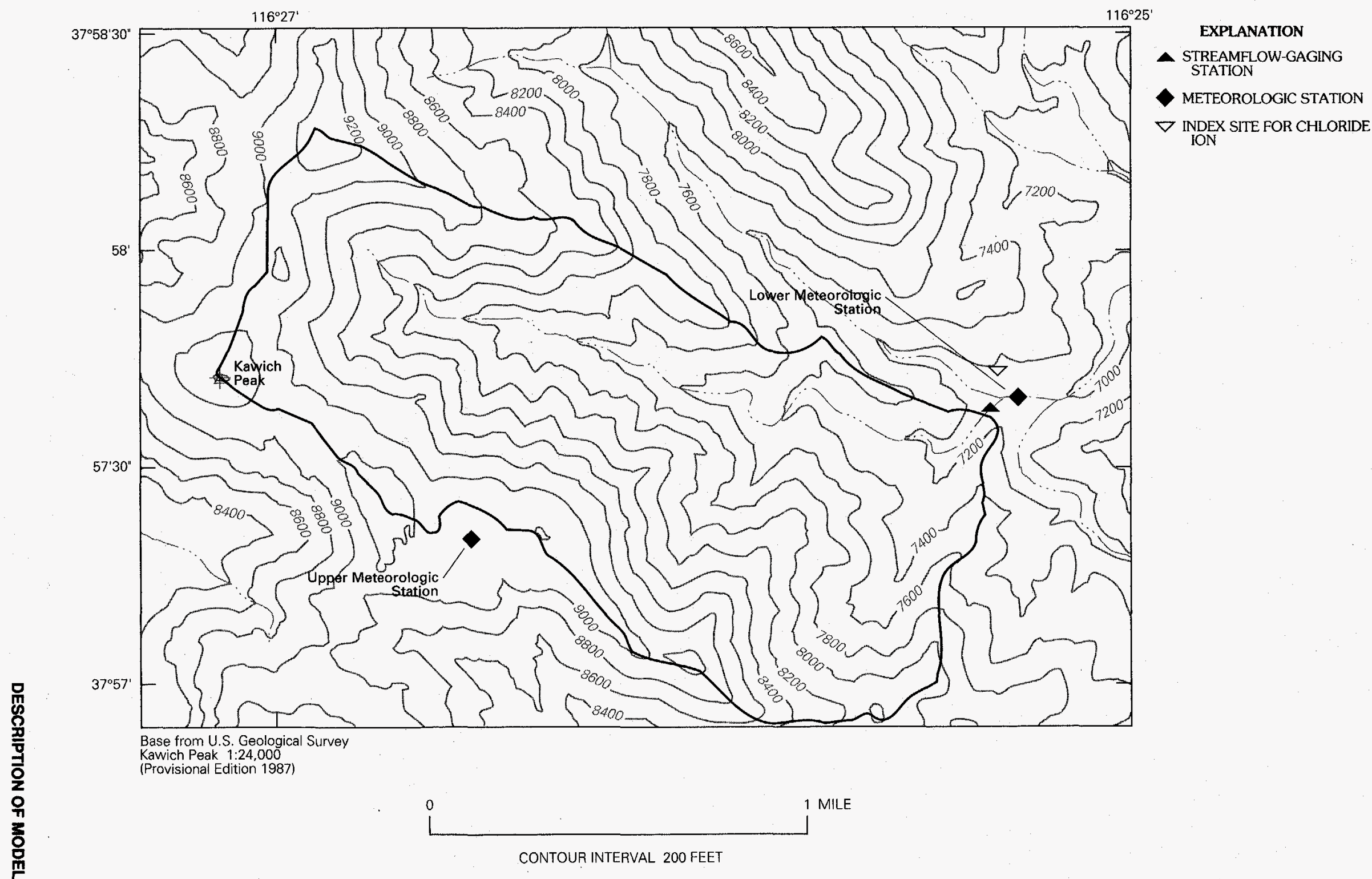

Figure 2. Topography of 3-Springs basin. 


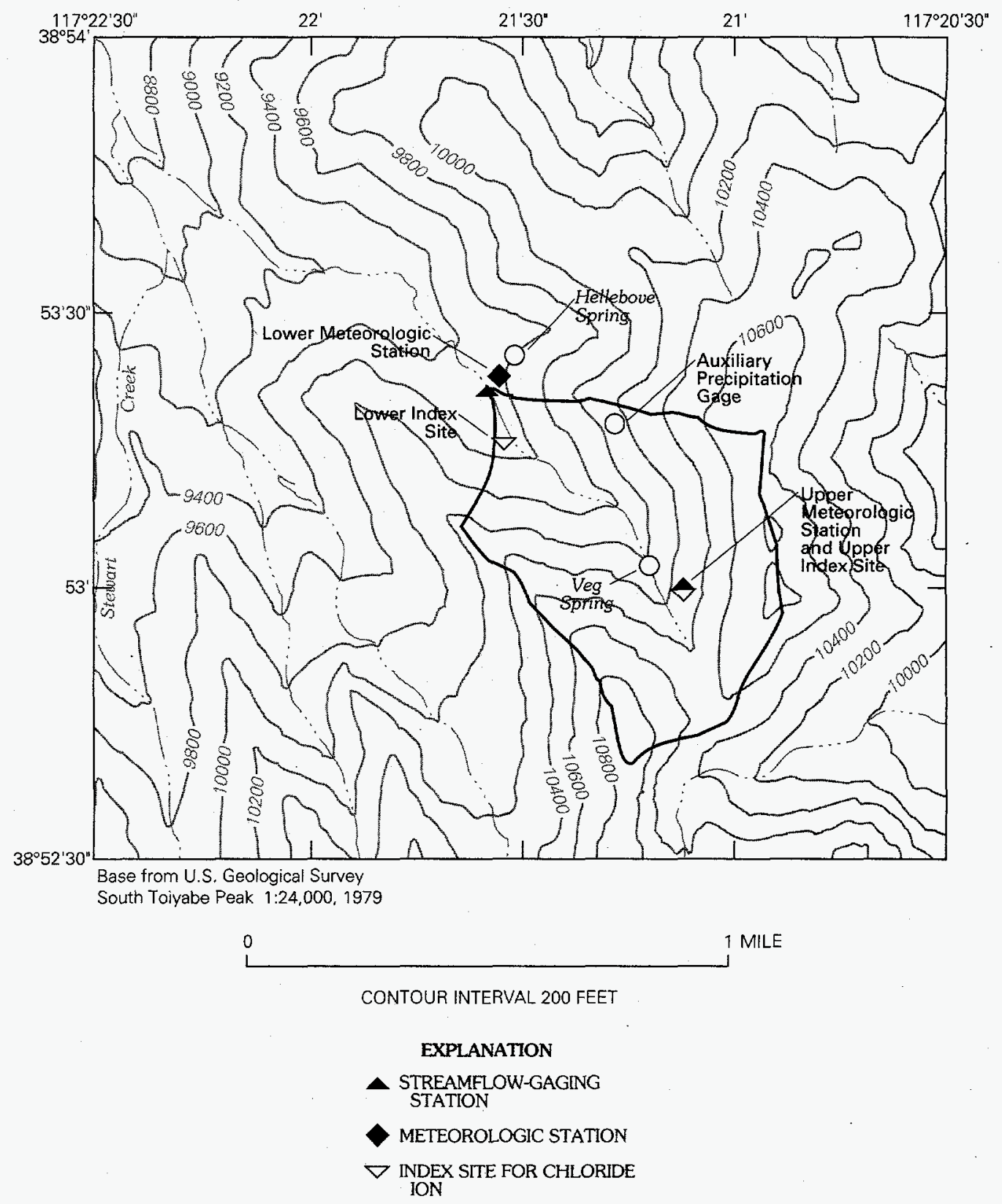

Figure 3. Topography of East Stewart Creek basin. 


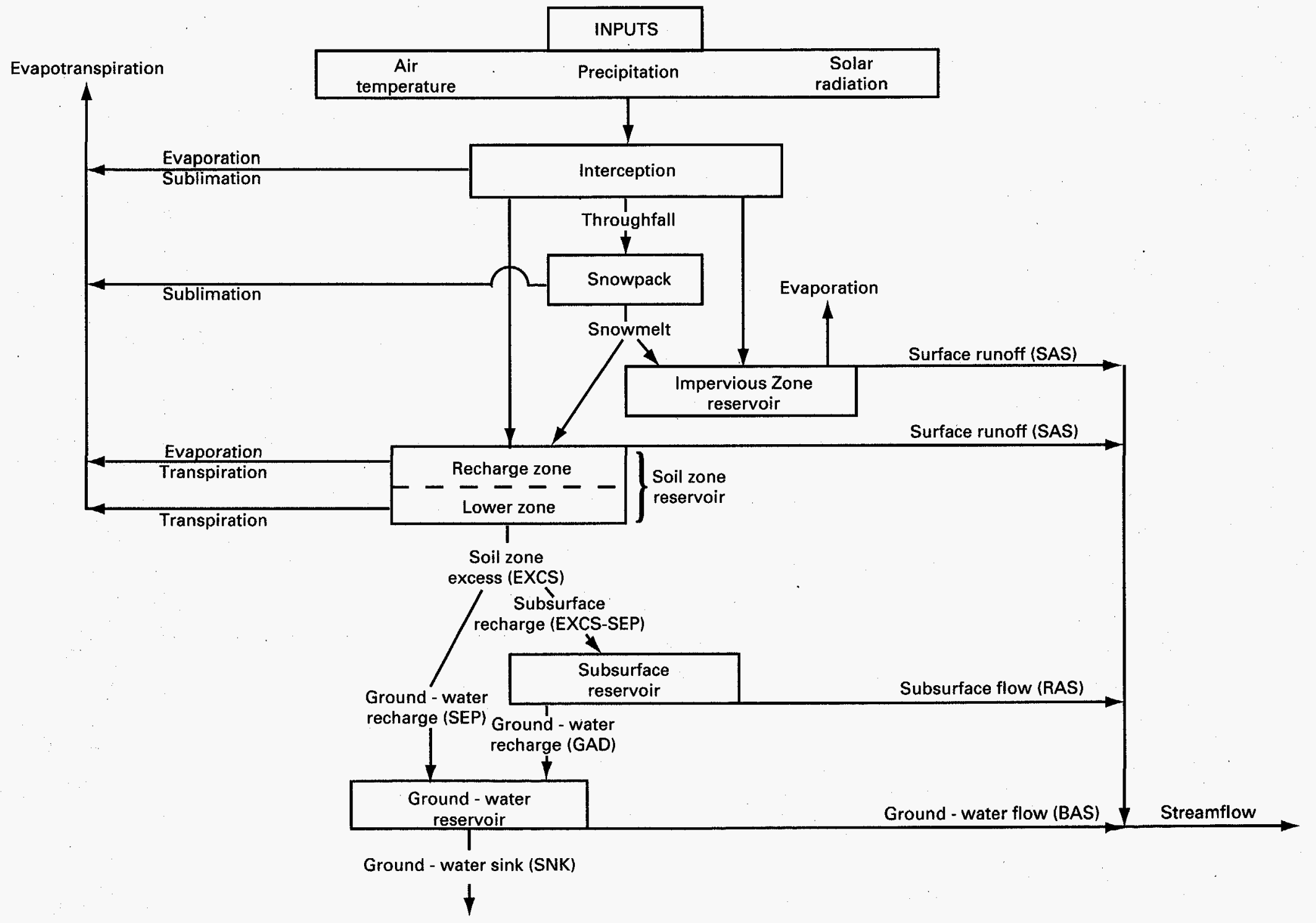

Figure 4. Schematic of the conceptual watershed system and its input (from Leavesley and others, 1983). 
perature based on HRU median elevation, and solar radiation adjusted to account for HRU-specific slope and aspect.

PRMS snow components simulate the initiation, accumulation, and depletion (ablation and melt) of a snowpack on each HRU. A snowpack water-

equivalent balance is computed daily, whereas the pack energy balance is updated twice daily for two 12-hour periods designated as day and night. The snowpack energy relationships were adapted from those described by Obled and Rosse (1977). The snowpack is assumed to be a two-layered system with a thin surface layer $(3-5 \mathrm{~cm})$ overlying the remaining snowpack. The designation of a surface layer facilitates the characterization of upper boundary conditions that are con- sidered separately from the underlying domain as is commonly done in such problems (Obled and Rosse, 1977). Figure 5 schematically illustrates the various components of the snowpack energy-balance equations (Leavesley and others, 1983, p. 39-46).

An accounting of soil moisture for each HRU involves additions of infiltrated water, either from rainfall or snowmelt, and depletions through evaporation and/or transpiration. Soil-moisture in excess of field capacity is allocated to the subsurface and groundwater reservoirs and eventually becomes the source of fair-weather streamflow subsurface flow (RAS) and ground-water flow (BAS) (fig. 4). The soil-zone reservoir is partitioned into an upper layer (termed the recharge zone) and a lower zone. The subdivision of

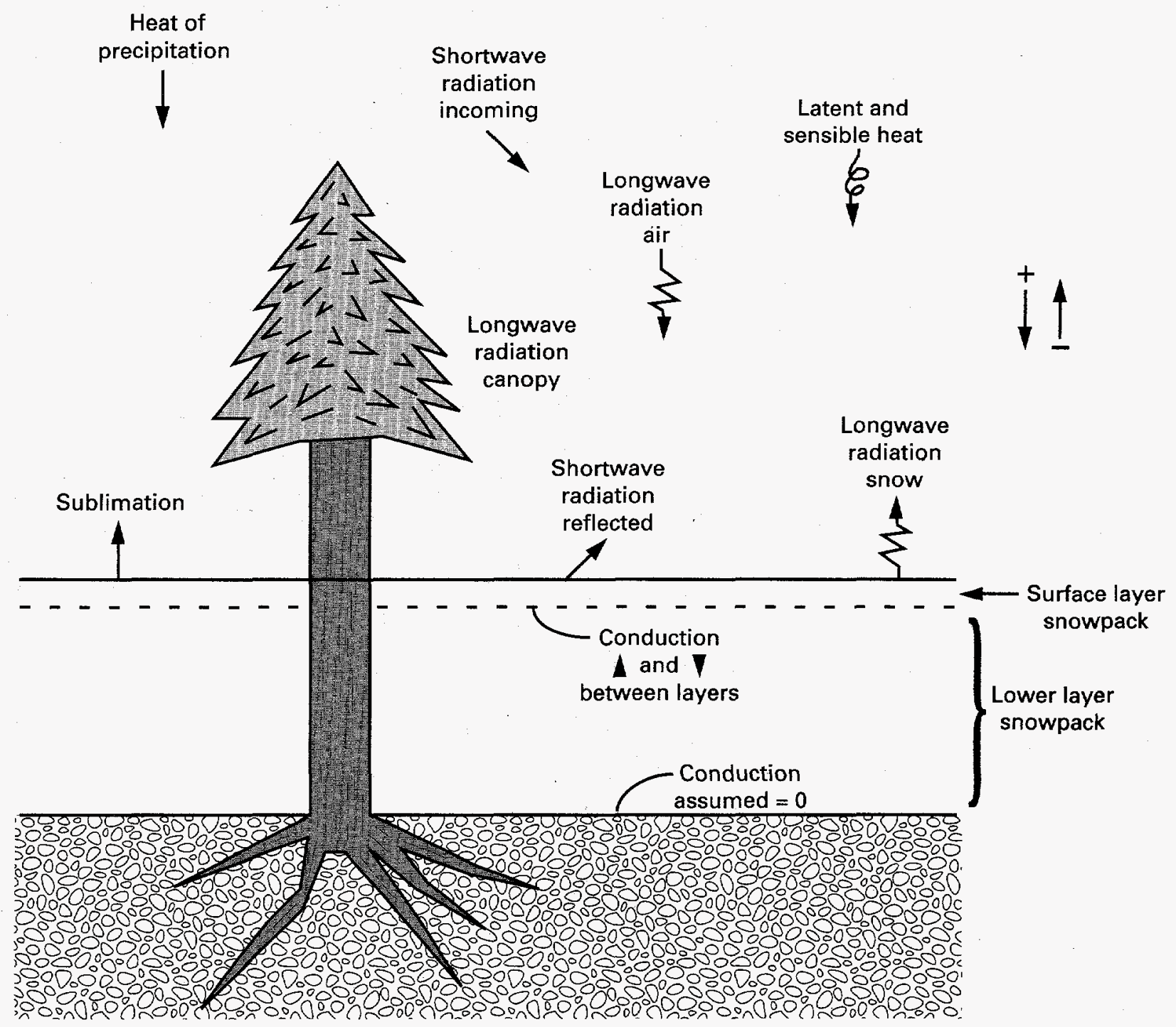

Figure 5. Components of the snowpack energy-balance equations (from Leavesley and others, 1983). 
the soil zone into two partitions accommodates the computation of evaporation and transpiration losses as follows: losses from the recharge zone are assumed from evaporation and transpiration; losses from the lower zone are only through transpiration. The maximum water-holding capacity of the soil-zone reservoir (SMAX) is a key factor in water-balance computations because it largely controls the amount of soil moisture available for evapotranspiration.

Infiltration into the soil zone is dependent on the source of input. All daily snowmelt is assumed to infiltrate the soil zone until field capacity moisture level is attained. At field capacity, snowmelt infiltration is limited to a maximum daily snowmelt-infiltration capacity, SRX. Snowmelt, in excess of the capacity rate, is allocated to surface runoff, SAS (fig. 4). Infiltration amounts that are in excess of the soil-zone capacity are the source of recharge to the subsurface and groundwater reservoirs, EXCS (fig. 4). Recharge to the ground-water reservoir has first priority and is limited to a maximum daily rate, SEP. Soil-zone excess, in an amount exceeding SEP, is allocated to the subsurface reservoir. Water available for infiltration resulting from rain on snow is treated as snowmelt, if the pack is not depleted, and as rainfall otherwise. Daily infiltration of rain falling on pervious, snow-free areas is the difference between net rainfall and computed surface runoff. Surface runoff is computed using a contributing-area concept that defines the percentage of runoff as a function of current soil-moisture level and net rainfall amount (Leavesley and others, 1983, p. 27).

Daily potential evapotranspiration, PET, is computed for each HRU using the Jensen-Haise equation (Jensen and Haise, 1963) that expresses PET as a multiplicative function of daily mean-air temperature and daily solar radiation expressed as an equivalent depth of evaporation of water. Actual evapotranspiration, AET, is the computed daily water loss that reflects the availability of water to satisfy PET demand. The availability of soil water for evapotranspiration is empirically defined for three broad soil-textural classes (that is, sand, clay, and loam), as modified from Zahner (1967).

The subsurface reservoir component represents a conceptualization of shallow ground-water zones (perched ground water) that respond rapidly to recharge from soil-water excess in amounts exceeding the ground-water recharge rate (EXCS minus SEP, fig. 4). Outflow from the subsurface reservoir to a stream channel is the source of the subsurface component of streamflow (RAS, fig. 4), also known as interflow (Linsley and others, 1958). Outflow to a stream channel from the subsurface reservoir can optionally be specified as a linear or nonlinear function of storage content. In addition, another outflow path from the subsurface reservoir can be optionally directed to the ground-water reservoir (buffered ground-water recharge, GAD, fig. 4).

Recharge to the ground-water reservoir occurs from soil-water excess, EXCS, and has an upper daily limit as specified by SEP. Optionally, a second source of ground-water recharge can be represented as the buffered recharge, GAD, described above. The routing of recharge through the ground-water reservoir is the source of all baseflow (BAS, fig. 4). The ground-water reservoir is assumed to function as a linear reservoir, with rate of outflow being directly proportional to storage content. Movement of ground water to points beyond the area of study or as ground-water underflow in valley alluvium, and therefore, not measured as discharge in a stream channel, is optionally simulated as a sink term (SNK, fig. 4), that is computed as a linear function of storage in the ground-water reservoir.

Streamflow (fig. 4) is the sum of three components: surface runoff (SAS), subsurface flow (RAS), and ground-water flow (BAS). Channel routing of the various streamflow components is not performed in the daily computation mode, as was the case in the application of PRMS to the analog study basins. Channel routing of streamflow components is not a significant consideration in applying PRMS to these small watersheds because traveltimes are negligible and the dominant flow components are ground-water and subsurface flow derived from snowmelt.

A completely unique specification of values for each of the components that comprise the conceptual watershed system is rarely attempted in defining HRU characteristics for small watershed applications. For example, a single subsurface reservoir and a single ground-water reservoir is often used to represent subsurface and ground-water flows from the entire watershed. That is, all HRU's contribute recharge to common subsurface and ground-water reservoirs. However, the availability of land-surface data (that is, slope, aspect, elevation, and canopy cover density) generally supports a detailed delineation of HRU's based on these important characteristics. This is particularly true in PRMS applications to watershed hydrologies that are dominated by snow accumulation/melt processes, as is the case for the analog study basins.

Listed in table 2 are some of the more important HRU properties affecting water-balance computations, in applications of PRMS to mountain watersheds, where snow is a prime consideration. The tabulation is adapted from one presented by Parker and Norris (1989). Three categories of characteristics are identified in table 2. Category 1 includes characteristics that are determined from regional climatic characteristics 
Table 2. Model input properties and their definitions

[Modified from Parker and Norris, 1989]

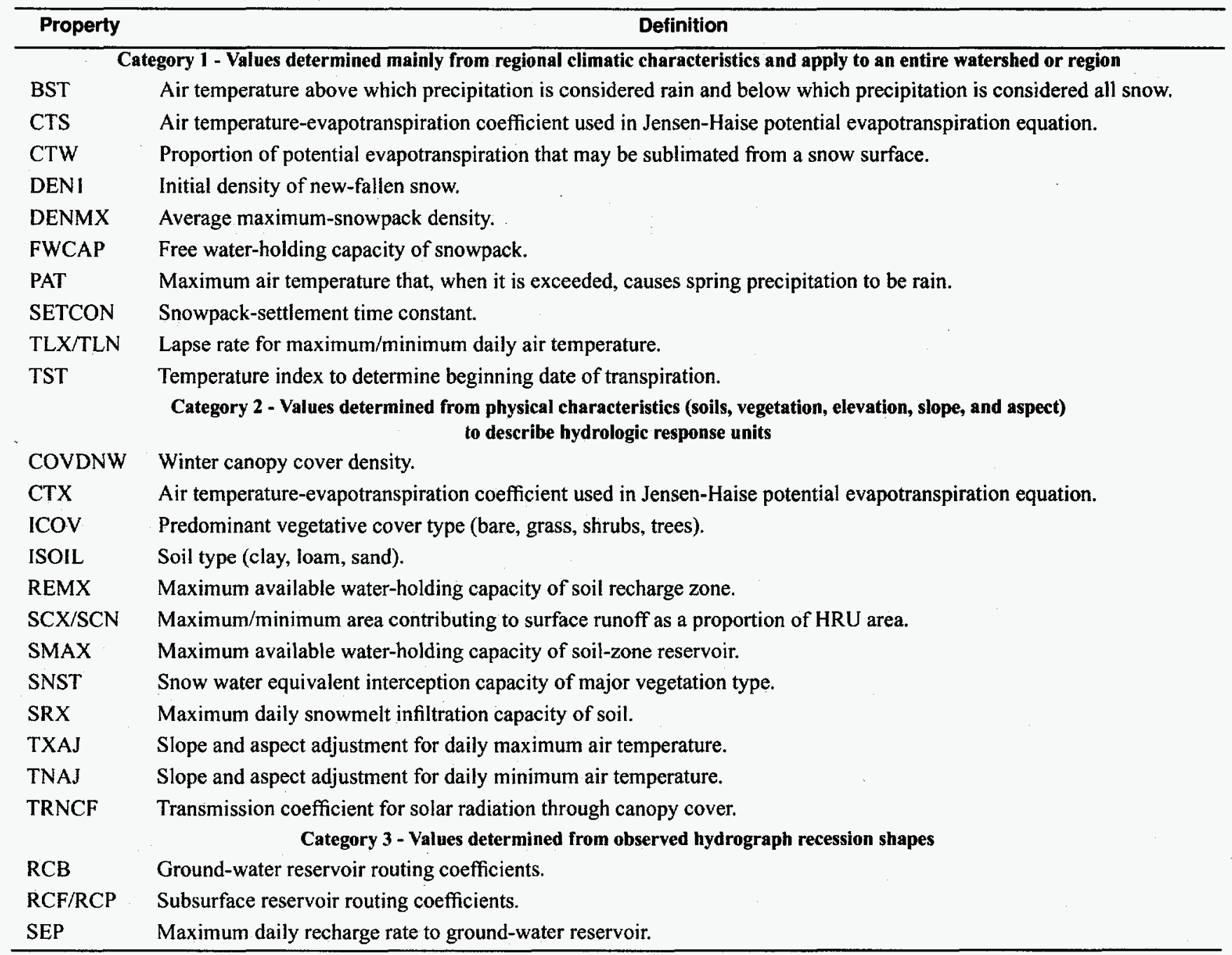

and apply to an entire drainage basin or region. Category 2 specifies characteristics that are distributed in nature and are the basis for subdividing a watershed into a particular HRU configuration. Category 3 identifies characteristics relating to subsurface and groundwater reservoirs that affect the magnitude, timing, and recession characteristics of simulated discharge hydrographs. The subsurface and ground-water routing characteristics are normally derived from observed streamflow data by hydrograph separation techniques.

\section{Chloride Model}

The use of the chloride ion in quantifying hydrologic water budgets is described by Claassen and others
(1986). The model is based on the conservative nature of the dissolved chloride ion in many hydrologic settings where the dominant source of the ion is from atmospheric deposition of precipitation on the land surface. Because of this constraint, the method cannot be applied to systems with a lithologic source of chloride unless these sources are accurately quantified. Fortunately, many geologic environments consisting of volcanic tuffs and intrusive rocks, as well as nonmarine sediments, quartzites, and other metamorphics contain limited sources of chloride and thus are appropriate environs for application of the model. Such is the case for the analog-recharge study basins.

Basically, the chloride model algorithm is a quantitative, basinwide accounting of the disposition of the mass of chloride deposited as a dissolved constitu- 
ent in the form of precipitation. Thus, the accurate measurement or estimation of basinwide precipitation is required. The methodology requires the measurement of chloride concentration and snow-water equivalent in precipitation at an index site. In addition, the index site is equipped with a buried canister into which snowmelt percolate accumulates, by gravity drainage through the soil mantle during the spring melt period. The volume of percolate and its chloride concentration are determined and used, along with the surface measurements, to develop a coupled, water and chloride, mass-balance system of equations to quantify, on a unit area basis, the amount of sublimation at the index site.

The mass-balance equation for water is

$$
P=E_{s}+E_{t}+R_{g}+R_{s}
$$

where,

$$
\begin{aligned}
& P=\text { precipitation; } \\
& E_{s}=\text { sublimation; } \\
& E_{t}=\text { transpiration; } \\
& R_{g}=\text { recharge (percolate); and } \\
& R_{s}=\text { surface runoff. }
\end{aligned}
$$

Equation 1 omits possible changes in soil-moisture storage because the water-holding capacity of the soil is assumed to be negligible. Transpiration losses during the snow accumulation/melt seasonal accounting period are small and $E_{t}=0$.

The mass-balance equation for chloride is

$$
\mathrm{Cl}_{\mathrm{p}}=\mathrm{Cl}_{\mathrm{Rg}}+\mathrm{Cl}_{\mathrm{Rs}}
$$

where,

$\mathrm{Cl}_{\mathrm{p}}=$ total chloride in precipitation;

$\mathrm{Cl}_{\mathrm{Rg}}=$ total chloride in recharge; and

$\mathrm{Cl}_{\mathrm{Rs}}=$ total chloride in surface runoff, with

$$
\begin{gathered}
\mathrm{Cl}_{\mathrm{p}}=\left[\mathrm{Cl}_{\mathrm{p}}\right] \mathrm{P} \\
\mathrm{Cl}_{\mathrm{Rg}}=\left[\mathrm{Cl}_{\mathrm{Rg}}\right] \mathrm{R}_{\mathrm{g}}
\end{gathered}
$$

and

$$
\mathrm{Cl}_{\mathrm{Rs}}=\left[\mathrm{Cl}_{\mathrm{Rs}}\right] \mathrm{R}_{\mathrm{s}}
$$

where the terms in brackets denote analytical concentrations. It is assumed that homogenization of the chloride ion occurs during the melting of the snowpack and that the concentrations of the ion are identical in the meltwater source of recharge and surface runoff. Therefore,

$$
\left[\mathrm{Cl}_{\mathrm{Rg}}\right]=\left[\mathrm{Cl}_{\mathrm{Rs}}\right]
$$

With the above assumptions the mass-balance equations reduce to

$$
P=E_{s}+R_{g}+R_{s}
$$

and

$$
\left[\mathrm{Cl}_{\mathrm{p}}\right] \mathrm{P}=\left[\mathrm{Cl}_{\mathrm{Rg}}\right] \mathrm{R}_{\mathrm{g}}+\left[\mathrm{Cl}_{\mathrm{Rg}}\right] \mathrm{R}_{\mathrm{s}}
$$

In this system of equations, all variables except $E_{s}$ and $\mathrm{R}_{\mathrm{s}}$ are quantified by direct measurement at the index site. Combining equations (7) and (8) and solving for $E_{S}$ results in

$$
\mathrm{E}_{\mathrm{s}}=\mathrm{P}\left\{1-\left[\mathrm{Cl}_{\mathrm{p}}\right] /\left[\mathrm{Cl}_{\mathrm{Rg}}\right]\right\}
$$

Thus, $E_{s}$ is computed as a function of measured quantities and $R_{s}$ is computed by use of equation 7. $E_{s}$ at the index site is then used in an extrapolation procedure to compute a basinwide estimate of sublimation and available water. Available water is defined as the difference between net precipitation input and sublimation loss. Thus, available water is the amount of potential runoff as quantified by the sum of $R_{g}$ and $R_{s}$, equation 7.

The extrapolation procedure uses a detailed specification of the physical factors that account for the spatial differences in net precipitation and snowpack sublimation over the watershed in relation to the specific conditions at the index site. Three primary factors affect the extrapolation of the computed amount of sublimation at the index site to accomplish a basinwide accounting of the elements of the hydrologic water balance (equation 7). These are (1) spatial variability of gross precipitation; (2) spatial variability of canopy cover density and associated interception losses; and (3) spatial variability of sublimation of snow on the ground due to differences in incident solar radiation as influenced by slope, aspect, and shading (a function of canopy cover density).

The spatial variability of precipitation over mountainous watersheds is often related to elevation. At-site observations of precipitation and, in some instances, supplemental snow-course data are used to define empirical relations for specific locals, as will be described in subsequent model applications to the analog study sites. The spatial variability of canopy cover density is typically defined by timber surveys, vegetational transect data, aerial photographs, and reconnaissance mapping. These types of field and office techniques were used to assess canopy cover density patterns for the two study basins. In addition, topographic quadrangle maps (40-ft contours) were used to quantify the slope and aspect of the individual HRU's (Appendices A, B). 
The effect of canopy cover density on interception is often defined by measurements of precipitation beneath various types and densities of tree canopy. These types of data are not available for the analog study basins. Therefore, an empirical relation between canopy cover density and interception developed by Claassen and others (1986) was assumed in computations for the analog basins. Claassen made measurements of interception loss under 100 percent Englemann spruce canopy density, and under no tree canopy (no interception loss). A linear relation between the two extremes was assumed (fig. 6) and corroborated by measurements made under lodgepole pine (Wilm and Dunford, 1948; U.S. Army, 1956).

The spatial variability of solar radiation over a watershed, due to differences in exposure (degree of slope and slope aspect), were determined by use of a well-documented algorithm for computing potential solar radiation on mountain slopes (Swift, 1976). The algorithm allows the computation of potential solar radiation on a daily basis. The cumulative daily poten- tial solar radiation for each HRU and also for the index site can be computed for the seasonal accounting period (about October 1 through June 1). These cumulative totals are used to compute a solar radiation adjustment factor, $S_{i}$, for each of the HRU's. The factor is defined as the ratio of potential solar radiation at the $\mathrm{i}$-th HRU to the potential radiation at the index site. The $S_{i}$ factors allow for transposition of the index site estimate of seasonal snowpack water loss by sublimation, $\mathrm{E}_{\mathrm{s}}$, to each of the HRU's.

Another important aspect of tree canopy density on forest hydrology is the shading of the snowpack from incident solar radiation. The effect of canopy cover on the amount of solar radiation reaching the snowpack is complex, as pointed out by Satterlund and Adams (1992, p. 182). Claassen and others (1986), presented a relationship between potential sublimation of snow on the ground (as a percent) and basal area (dimensionless ratio of tree cross-sectional area to land-surface area). The relation was developed from

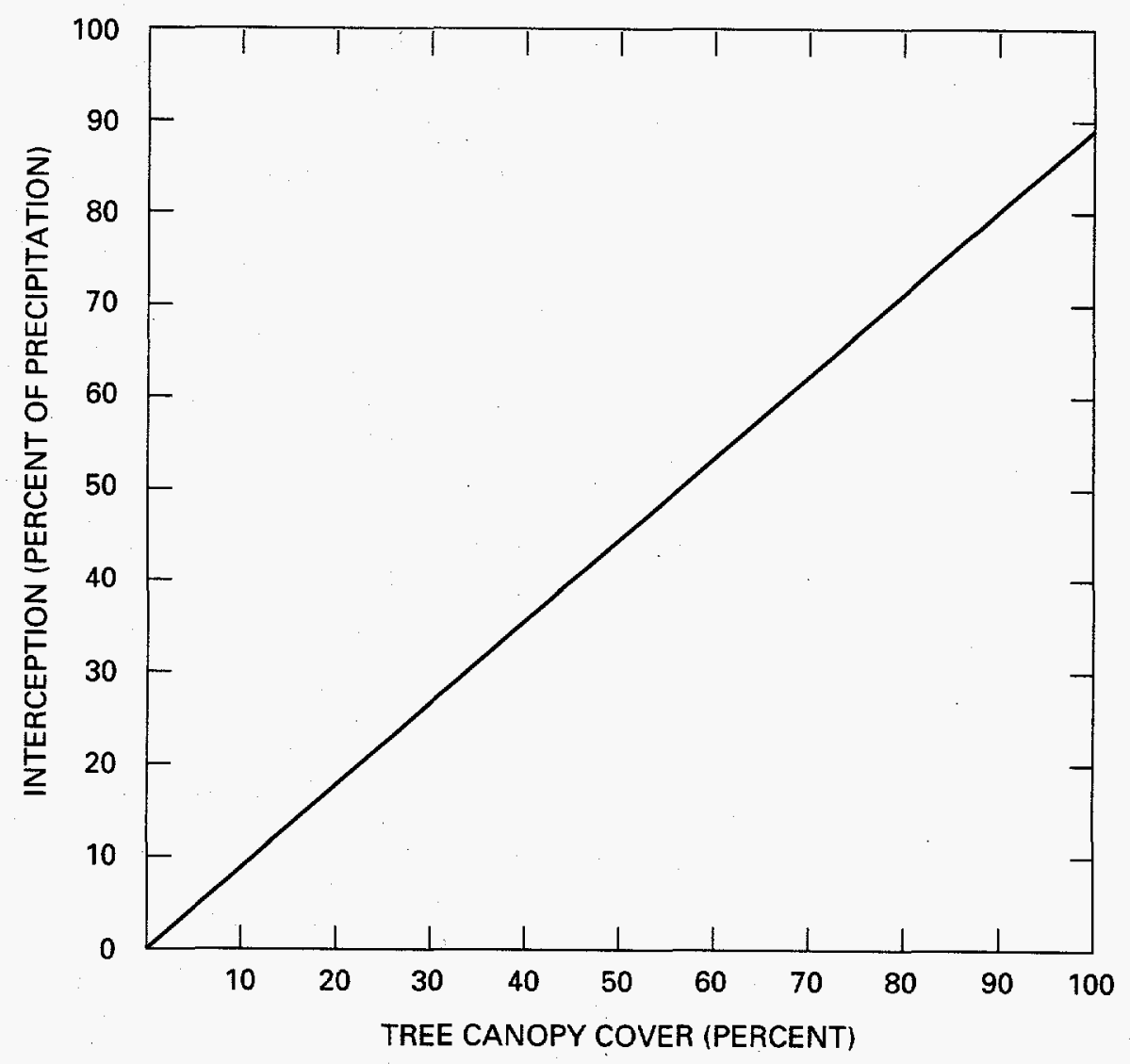

Figure 6. Effect of tree-canopy density on snow interception (modified from Claassen and others, 1986). 
curves presented in Satterlund (1972, p. 169) and measurements of basal area and tree-canopy density from at-site data for their study area (Deep Creek basin in southwestern Colorado).

Because of the lack of required basal-area measurements at the study basins, another approach was used to account for the shading effects on snowpack sublimation caused by tree-canopy cover density. This approach is the so-called transmission coefficient method and is based on either measured or assumed functional relations describing the filter effect of forest canopy cover density on incident solar radiation at the snowpack. Examples of such relationships are shown in figure 7, taken from the snow accumulation/melt algorithms described by Leavesley and others (1983). The assumed relation, shown in figure 7 , was used in the procedure to extrapolate index-site estimates of sublimation, $\mathrm{E}_{\mathrm{s}}$, for basinwide computations at the study sites.

Thus, the algorithm for calculation of available moisture, $\mathrm{N}_{\mathrm{i}}$, for each HRU is expressed as follows:

$$
N_{i}=P_{i}-I_{i}-\left(S_{i}\right)\left(P S_{i}\right)\left(E_{s}\right)
$$

where,

$$
\begin{aligned}
\mathrm{P}_{\mathrm{i}}= & \text { gross precipitation; } \\
\mathrm{I}_{\mathrm{i}}= & \text { interception loss; } \\
\mathrm{S}_{\mathrm{i}}= & \text { solar radiation factor; } \\
\mathrm{PS}_{\mathrm{i}}= & \text { potential sublimation as influenced by } \\
& \text { shading (fig. 7); and } \\
\mathrm{E}_{\mathrm{s}}{ }^{\prime}= & \text { the computed sublimation at the index site } \\
& \text { corrected for shading at that site. }
\end{aligned}
$$

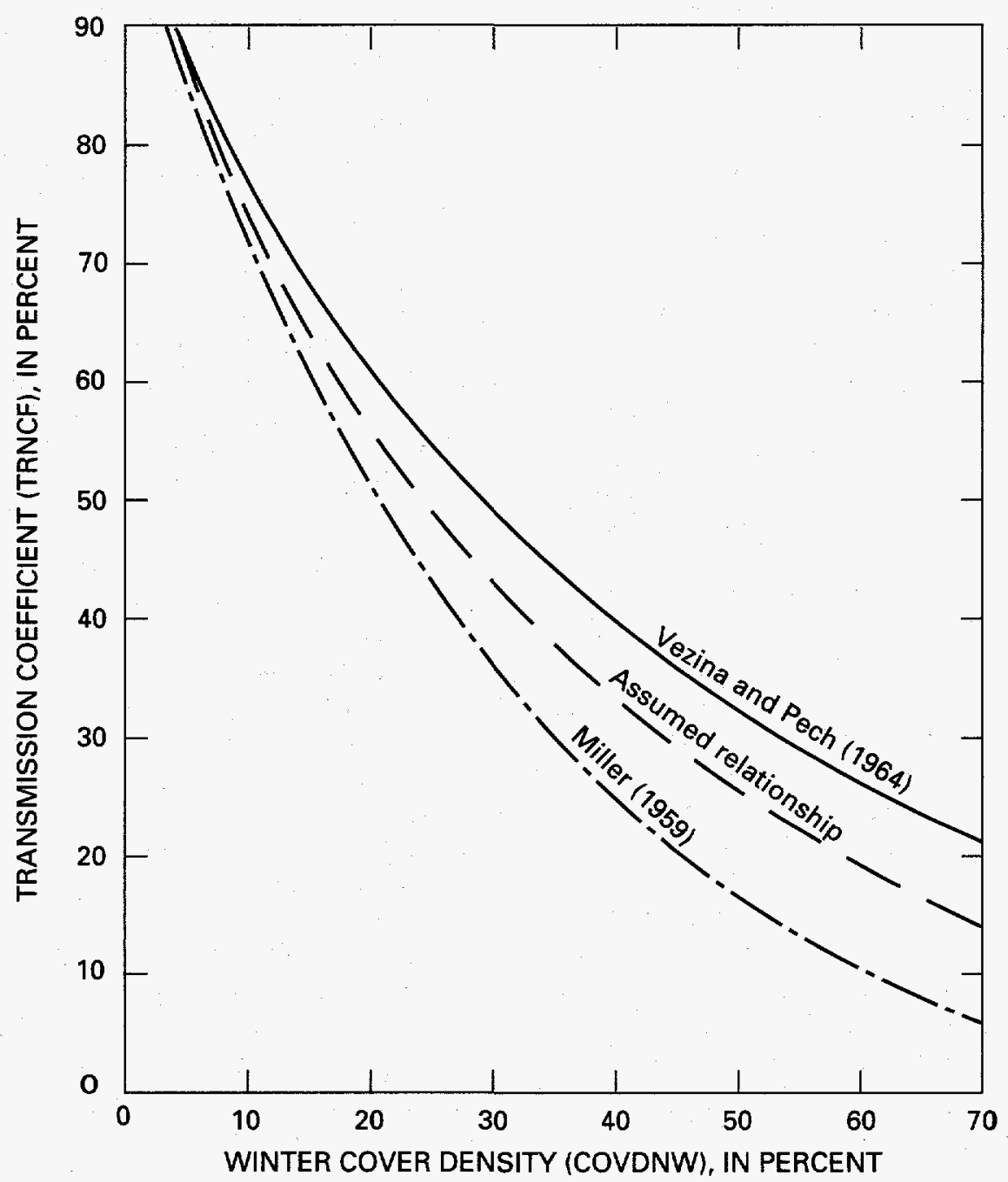

Figure 7. Functional relations between winter forest-cover density (COVDNW) and the transmission coefficient (TRNCF) of the forest canopy (from Leavesley and others, 1983). 
That is, $E_{s}^{\prime}$ represents the index-site sublimation corrected to an open-area exposure. If the index site is located in an open area, then $E_{s}{ }^{\prime}=E_{s}$ and no correction is required as was the case for the study basins.

Available moisture for the basin is the areaweighted sum of $\mathrm{N}_{\mathrm{i}}$ over the total of all HRU's. The basinwide estimate of available moisture can be partitioned into a ground-water recharge component and a surface-runoff component in the same proportion as indicated by the index-site computations.

The above discussion of the chloride-ion method of determining hydrologic water budgets is an abridged version of the detailed, in-depth description presented by Claassen and others (1986). In particular, the authors give extensive information on required sampling devices, sample collection and preservation techniques, and experimental design.

\section{APPLICATION OF PRMS TO ANALOG STUDY BASINS}

In contrast to the chloride-ion modeling approach, PRMS must be calibrated to best reproduce observed discharge data. It was earlier stated that the chloride-ion model yields estimates of hydrologic water-balance elements based on an extrapolation of results of computations made using data collected at an index site. The index site results are, therefore, the "calibration" of the chloride model. The calibration of PRMS using site-specific data is an iterative process that entails either (1) manual adjustment of selected characteristics to achieve specific simulated responses, and/or (2) automated parameter adjustments (optimization), so as to minimize the difference between simulated and observed daily-mean discharge.

The application of PRMS to the study basins used both manual and automated adjustment of characteristics in the fitting process. Manual adjustment of characteristics was the choice in the initial phases, so as to gain a feel for model response characteristics in these two diverse hydrologic settings. In addition, these initial efforts used a simplified configuration of HRU's, because the focus of attention was on general levels of water-balance components, and their sensitivity to characteristics quantifying (1) maximum available water-holding capacity of the soil zone, SMAX, and (2) potential evapotranspiration demand, CTS. These two characteristics largely characterize the "supply" and "demand" functions that strongly impact the annual water balance for 3-Springs and East Stewart basins.

Another important task of the initial fitting for East Stewart basin was the accurate simulation of the magnitude and timing of snowmelt as influenced by (1) correction factor for gage-catch deficiency for snowfall, DSCOR, and (2) the areal extent of snow cover as characterized by a snow cover areal depletion curve. A snow cover areal depletion curve depicts the relation between the areal extent of snow cover (percent) and a ratio defined as the current snowpack water equivalent divided by a threshold value of water equivalent associated with 100 percent areal snow cover (Anderson, 1973). The snow cover areal depletion curve is used to determine the percent of the area that is covered by snow, and thus, the portion of the area over which energy exchange is taking place during the melt phase of snowpack modeling.

\section{3-Springs Basin}

The data available for analysis at 3-Springs basin consists of daily mean discharge, daily precipitation, maximum and minimum daily temperature, and daily solar radiation for water years 1987 through 1992 (McKinley and Oliver, 1994, 1995). The water year (WY) is the 12-month period October 1 through September 30 and is designated by the calendar year in which it ends. Because of the semiarid nature of the prevailing climate and hydrologic characteristics at 3-Springs basin, mean annual runoff for the 6-year study period averaged only about 3 percent of basinwide precipitation (average annual runoff $=1.07 \mathrm{~cm}$, average annual basinwide precipitation $=33.63 \mathrm{~cm}$ ). Maximum annual runoff of $4.62 \mathrm{~cm}$ occurred in WY 1988 and was associated with the maximum annual basinwide precipitation value of $43.48 \mathrm{~cm}$.

Basinwide precipitation values represent an adjustment to observed data values to account for the empirical relationship between land-surface altitude and yearly snow-season totals (September through May) as determined from a lower (3-Springs basin) and upper (Kawich Peak) precipitation-gaging site. The altitude of the base gage is $2,155 \mathrm{~m}$ and that at the upper gage is $2,755 \mathrm{~m}$. The basinwide, snow-season precipitation total reflects an increase of 18 percent over the amount recorded at the lower gage (basinwide average snow correction factor of 1.18). Annual precipitation amounts reflect an increase of about 12 percent over that recorded at the lower gage.

Because of the sparseness of control data (mean daily discharge), little could be gained by undertaking an elaborate parameter-fitting scheme involving iterative optimization runs, coupled with sensitivity analysis. Therefore, a simple approach to parameter adjustments was undertaken in order to confirm the applicability of PRMS to hydrologic settings typified 
by 3 -Springs basin. As mentioned previously, potential evapotranspiration demand is an important factor influencing water-balance computations. The parameter CTS of the Jensen-Haise equation largely controls the magnitude of PET estimates because it functions as a multiplicative scaling parameter in the equation formulation. An estimate of the value of CTS (0.013) for 3-Springs basin was computed using appropriately quantified values of the elevation correction factor (a function of median elevation of the watershed), and the humidity index (a function of saturation vapor pressures for the mean maximum and mean minimum air temperatures for warmest month of the year) as described in Leavesley and others (1983).

Listed in table 3 are annual values and period averages of simulated potential evapotranspiration demand for three levels of the parameter CTS. Level 1 is a 10 percent reduction in the basin evaluation of CTS $=0.013$, that is, CTS $=0.0117$. Level 3 is a 10 percent increase in the basin value, or CTS $=0.0143$. Level 2 is the estimated basin value of, CTS $=0.013$. The period average value of $115.3 \mathrm{~cm}$, for CTS = 0.013 , closely approximates an independent estimate of $114 \mathrm{~cm}$, as indicated on "Map 3, Annual free water surface evaporation" (U.S. Department of Commerce, 1982). Similarly, the average seasonal (May-October) value of $93.2 \mathrm{~cm}$ compares closely with the value of $89 \mathrm{~cm}$ as indicated on "Map 2, May-October free water surface evaporation" (U.S. Department of Commerce, 1982).

Table 3. Sensitivity of simulated annual potential evapotranspiration demand to CTS for 3-Springs basin

[cm, centimeter; CTS, air temperature-evapotranspiration coefficient used in Jensen-Haise potential evapotranspiration equation]

\begin{tabular}{crcc}
\hline & \multicolumn{3}{c}{$\begin{array}{c}\text { Potential evapotranspiration demand } \\
(\mathbf{c m}) \text { for given values of }\end{array}$} \\
\cline { 2 - 4 } Water year
\end{tabular}

Observed annual runoff and precipitation data are listed in table 4, along with PRMS simulation results for each of five values of the parameter quantifying the maximum available water-holding capacity of the soil zone, SMAX. A comparison of observed and simulated results indicates that a value of SMAX of about $15 \mathrm{~cm}$ would be close to an optimal value. For example, SMAX $=15.24$ results in a 6-year average annual simulated runoff value of $1.17 \mathrm{~cm}$, as compared with the observed value of $1.07 \mathrm{~cm}$. Also, in two instances (1988 and 1992), the results of simulation using SMAX = 15.24 indicate departures from observed data in excess of $1.8 \mathrm{~cm}$. Errors of this magnitude can easily be attributed to subtle discrepancies (errors) in basinwide precipitation input and/or unmodeled, real-world phenomena such as winds that rapidly deplete a snowpack.

Additional insight into the utility of PRMS to simulate hydrologic conditions for 3-Springs basin is indicated by comparison of observed and simulated snowpack water equivalents listed in table 5 . The two snow courses were established in 1989 in close proximity to the lower and upper precipitation-gaging sites. The intended purpose of these site locations was to assess the variability in snowpack conditions and their relation to gaged precipitation amounts. It should be noted that the upper snow course is located in a shallow bowl, about $100 \mathrm{~m}$ south of the drainage divide (fig. 2) and may experience somewhat different snow accumulation patterns than the typical slopes of the basin. The simulated basinwide values of snowpack water equivalent compare best with the data values for the lower snow course.

A summary of PRMS simulation results is listed in table 6. The column headings identify the major elements of the hydrologic water balance for each water year of simulated and observed data (1987-92). Also shown in table 6 are period averages that indicate the dominance of the subsurface components of simulated streamflow (RAS and BAS) over surface runoff. The sum of these two flow components indicates an average annual recharge to shallow and deep ground water of $1.14 \mathrm{~cm}$. Observed average annual runoff for the 6-year period is $1.07 \mathrm{~cm}$.

Hydrograph plots of observed and simulated daily-mean discharge for the period of study (water years 1987 through 1992) are shown in figures 8 and 9. There is reasonably good agreement between observed and simulated hydrograph timing, but that volume runoff amounts for discrete melt periods indicate wide dispersion. The errors in simulated runoff volumes are a consequence of the fact that observed and simulated runoff are a small fraction of basinwide precipitation, and errors of this magnitude are to be expected under these difficult modeling conditions. 
Table 4. Sensitivity of simulated annual runoff to SMAX for 3-Springs basin

[cm, centimeter; SMAX, maximum available water-holding capacity of soil-zone reservoir in centimeters]

\begin{tabular}{cccccccc}
\hline Water year & $\begin{array}{c}\text { Basinwide } \\
\text { precipitation } \\
\end{array}$ & $\begin{array}{c}\text { Observed runoff } \\
(\mathbf{c m})\end{array}$ & & \multicolumn{5}{c}{ Simulated runoff $(\mathbf{c m})$ for given values of SMAX } \\
\cline { 5 - 8 } & 26.80 & 0.46 & $\mathbf{5 . 0 8}$ & $\mathbf{1 0 . 1 6}$ & $\mathbf{1 5 . 2 4}$ & $\mathbf{2 0 . 3 2}$ & $\mathbf{2 5 . 4 0}$ \\
\hline 1987 & 43.48 & 4.67 & 14.07 & 6.96 & 0.30 & 0.03 & 0.01 \\
1988 & 28.52 & 0.03 & 3.99 & 1.22 & 0.43 & 0.18 & 0.05 \\
1989 & 29.95 & 0.00 & 3.12 & 0.48 & 0.13 & 0.08 & 0.05 \\
1990 & 37.95 & 0.10 & 5.31 & 1.70 & 0.46 & 0.10 & 0.05 \\
1991 & 35.05 & 1.09 & 10.36 & 6.12 & 2.97 & 1.09 & 0.15 \\
1992 & 33.63 & 1.07 & 7.01 & 3.00 & 1.17 & 0.43 & 0.10 \\
Period average & & & & &
\end{tabular}

Table 5. Simulated and observed snowpack water equivalents for 3-Springs basin

[cm, centimeter]

\begin{tabular}{lccc}
\hline Date & $\begin{array}{c}\text { Simulated } \\
\text { basinwide } \\
\text { water } \\
\text { equivalent } \\
\text { (cm) }\end{array}$ & $\begin{array}{c}\text { Snowpack water } \\
\text { equivalents }\end{array}$ \\
\cline { 3 - 4 } & $\begin{array}{c}\text { Lowersnow } \\
\text { course } \\
\text { (cm) }\end{array}$ & $\begin{array}{c}\text { Upper snow } \\
\text { course } \\
\text { (cm) }\end{array}$ \\
\hline February 23, 1989 & 8.23 & 6.9 & 14.2 \\
January 30, 1990 & 3.15 & 3.8 & 5.3 \\
January 30, 1991 & 0.81 & 0.0 & 3.8 \\
February 18, 1992 & 13.23 & 13.0 & 18.8 \\
April 08, 1992 & 1.98 & 0.0 & 19.0 \\
\hline
\end{tabular}

Table 6. Summary of simulation results for 3-Springs basin

[PPT, precipitation; PET, potential evapotranspiration; AET, actual evaporation, sublimation, and evapotranspiration from canopy, snowpack, and soil zone; SAS, overland flow to stream; RAS, subsurface flow to stream; BAS, ground-water flow to stream; SUM, total simulated streamflow; OBS, observed streamflow; cm, centimeter]

\begin{tabular}{|c|c|c|c|c|c|c|c|c|c|}
\hline \multirow[b]{2}{*}{ Water year } & \multirow{2}{*}{$\begin{array}{l}\text { PPT } \\
(\mathrm{cm})\end{array}$} & \multirow{2}{*}{$\begin{array}{l}\text { PET } \\
(\mathrm{cm})\end{array}$} & \multirow{2}{*}{$\begin{array}{l}\text { AET } \\
(\mathrm{cm})\end{array}$} & \multirow{2}{*}{$\begin{array}{l}\text { Change in } \\
\text { storage } \\
\text { (cm) }\end{array}$} & \multicolumn{3}{|c|}{ Components of streamflow } & \multirow{2}{*}{$\begin{array}{l}\text { SUM } \\
\text { (cm) }\end{array}$} & \multirow{2}{*}{$\begin{array}{l}\text { OBS } \\
\text { (cm) }\end{array}$} \\
\hline & & & & & $\begin{array}{l}\text { SAS } \\
(\mathrm{cm})\end{array}$ & $\begin{array}{l}\text { RAS } \\
\text { (cm) }\end{array}$ & $\begin{array}{l}\text { BAS } \\
\text { (cm) }\end{array}$ & & \\
\hline 1987 & 26.80 & 708.74 & 27.99 & -1.50 & 0.03 & 0.20 & 0.08 & 0.31 & $\overline{0.46}$ \\
\hline 1988 & 43.48 & 116.71 & 39.27 & 1.42 & 0.13 & 1.91 & 0.76 & 2.80 & 4.67 \\
\hline 1989 & 28.52 & 124.82 & 28.75 & -0.69 & 0.02 & 0.03 & 0.41 & 0.46 & 0.03 \\
\hline 1990 & 29.95 & 117.91 & 28.63 & 1.19 & 0.05 & 0.02 & 0.05 & 0.12 & 0.00 \\
\hline 1991 & 37.95 & 105.82 & 36.93 & 0.56 & 0.05 & 0.30 & 0.10 & 0.45 & 0.10 \\
\hline 1992 & 35.05 & 115.34 & 32.41 & -0.33 & 0.03 & 2.11 & 0.84 & 2.98 & 1.09 \\
\hline Period average & 33.63 & 115.27 & 32.33 & 0.10 & 0.05 & 0.76 & 0.38 & 1.19 & 1.07 \\
\hline
\end{tabular}




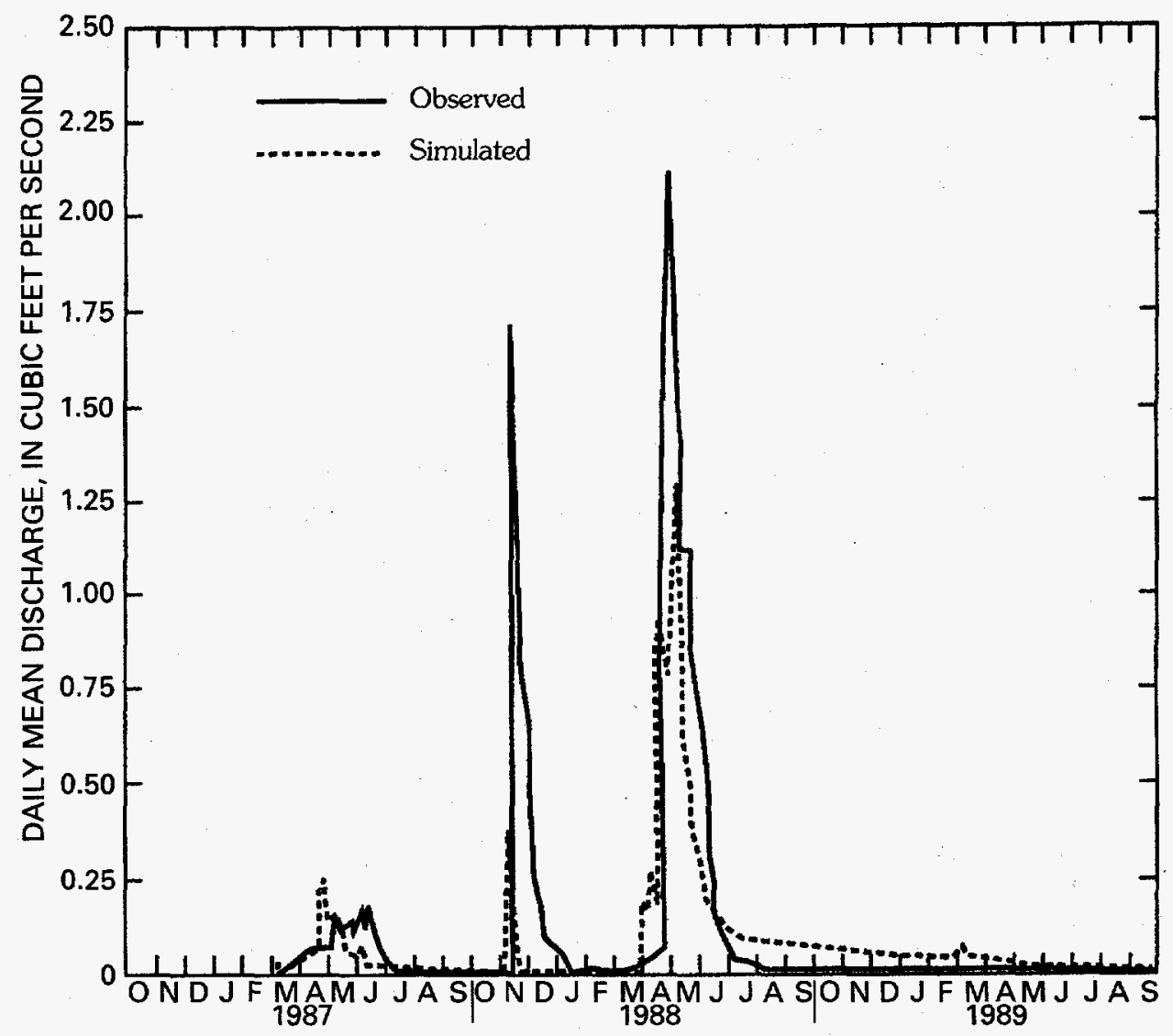

Figure 8. Observed and simulated daily-mean discharge for water years 1987 through 1989 of 3-Springs Creek, Central Nevada.

\section{East Stewart Creek Basin}

The data available for analysis at East Stewart Creek basin are considerably more extensive than that at 3-Springs basin and consists of daily mean discharge, daily precipitation at two locations (a lowerand upper-basin gaging site), maximum and minimum daily temperature, and daily solar radiation for water years 1987 through 1992 (McKinley and Oliver, 1994, 1995). It should be noted that the initial observation of streamflow was made on May 7,1987. Total runoff for the period October 1, 1986, through May 6, 1987, was estimated to be $7.95 \mathrm{~cm}$ from a like period average of observed data (five periods) that exhibits low annual variability. East Stewart Creek basin is located to the north of 3-Springs basin and is situated at a higher median-basin altitude. For these reasons, East Stewart basin experiences cooler temperatures and higher precipitation amounts than 3-Springs basin. Mean-annual precipitation at East Stewart basin is almost double that at 3-Springs basin, and almost all the increase in annual precipitation is recorded as runoff in streamflow measured at the gaging station (table 1).

The fitting of PRMS to best reproduce observed discharge at the East Stewart Creek stream-gaging site involved an iterative sequence of trial adjustments to three characteristics that grossly affect simulated results. Two of the characteristics affect the magnitude of simulated annual runoff (SMAX, maximum available water-holding capacity of the soil zone, and DSCOR, daily precipitation adjustment factor for snowfall). The third parameter (SEP, maximum daily recharge rate to ground-water reservoir) controls the partitioning of simulated runoff derived from the subsurface and ground-water reservoirs (fig. 4). Analysis of observed hydrograph recessions, following the guidelines outlined in Leavesley and others (1983, p. 32-34), provided the required subsurface and 


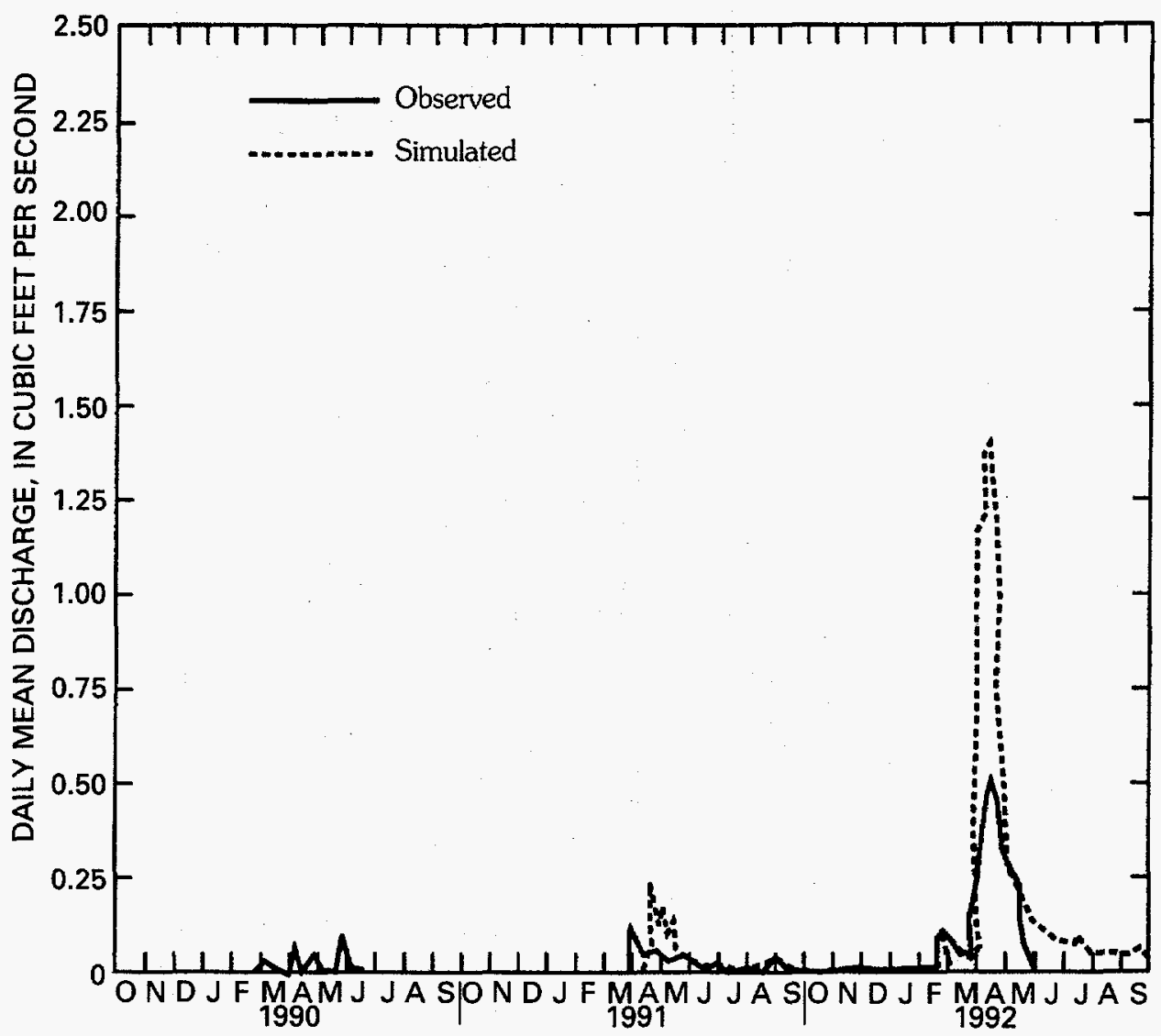

Figure 9. Observed and simulated daily-mean discharge for water years 1990 through 1992 of 3-Springs Creek, Central Nevada.

ground-water reservoir routing coefficients, RCF and RCB.

A comparison of observed data and initial simulation results indicated that modeled snowpack water equivalents were generally too low and that a winter season daily snowfall correction factor of about 1.3 (30-percent increase) would be required to approximate both the observed snowpack water equivalents as well as observed annual runoff. There is no discernible elevational relationship between winter season precipitation amounts as recorded at the lower- and upperbasin gaging sites. Therefore, the daily snow correction factor was assumed to apply to the winter season records at both the lower- and upper-gaging sites. In addition, these initial runs revealed that modeled snowmelt occurred too early and needed to be retarded in time in order to better match observed discharge. A snow cover areal depletion curve (curve B, fig. 10) adapted from Anderson (1973) was used to rectify the timing deficiencies.
Basinwide annual precipitation and observed runoff data are listed in table 7, along with PRMS simulation results for each of three values of the parameter $\operatorname{SMAX}(1.27,2.54$, and $3.81 \mathrm{~cm})$. An optimal value of SMAX of between 1.27 and $2.54 \mathrm{~cm}$ is indicated. Recall that SMAX equals $15 \mathrm{~cm}$ was the appropriate value for 3-Springs basin. Values of SMAX as low as 1.27 to $2.54 \mathrm{~cm}$ are rare and indicative of a shallow, coarse, and highly permeable soil zone. The results presented in table 7 are conditioned on the use of the aforementioned value of DSCOR $=1.3$, and also the snow cover areal depletion curve (curve B, fig. 10).

Table 8 shows a comparison of simulated, basinwide, snowpack water equivalents and those observed at the lower- and upper-basin snow courses (these results are conditioned on the use of $S M A X=2.54 \mathrm{~cm}$, $\mathrm{DSCOR}=1.3$, and the areal depletion curve). Note that the simulated results are often within the range of values of the observed data. This is a self-fulfilling outcome that was achieved by the trial adjustments resulting in the fitted value of DSCOR $=1.3$. 


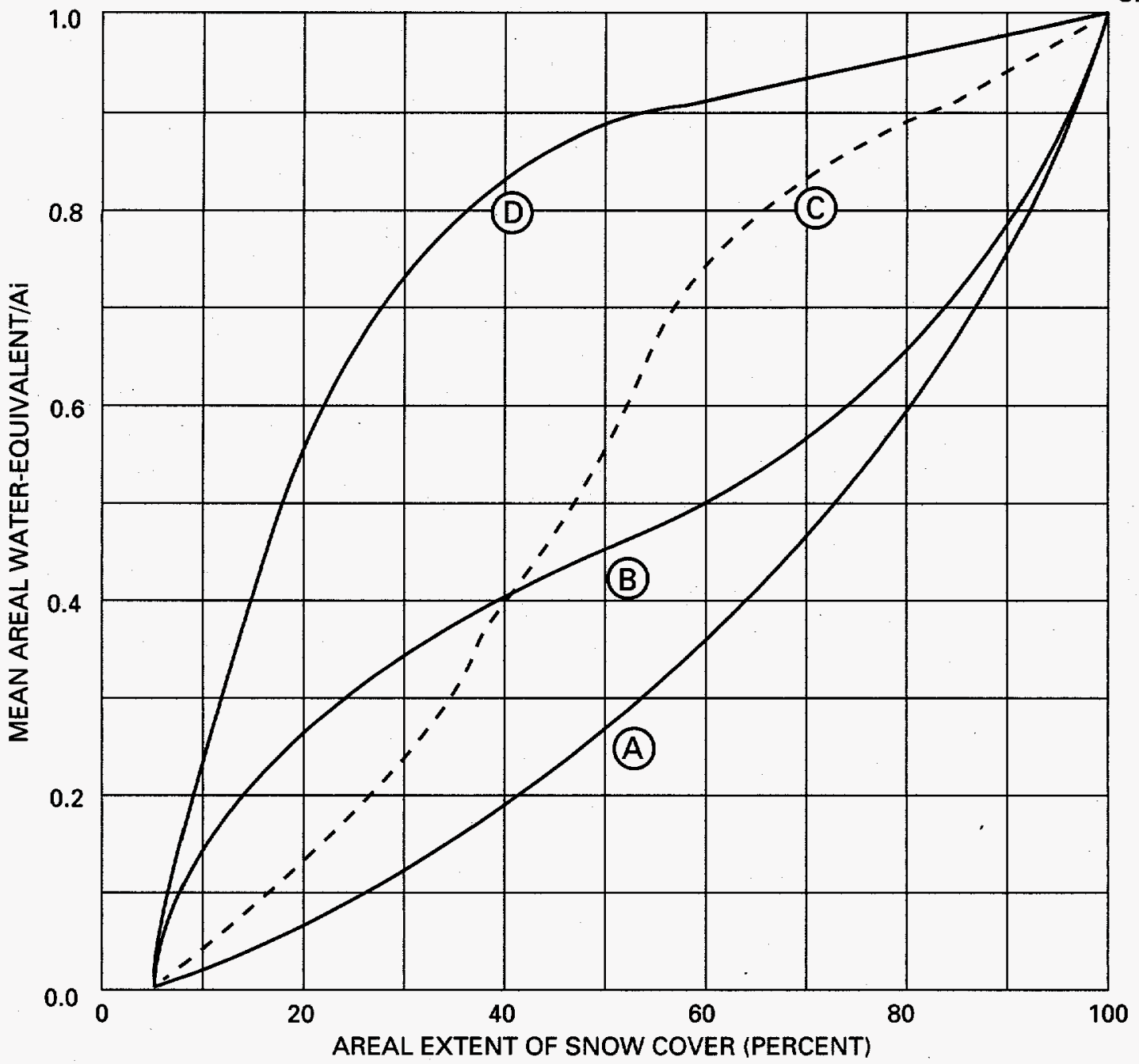

Figure 10. Characteristic shapes of snow cover areal depletion curves.

Table 7. Sensitivity of simulated annual runoff to SMAX, East Stewart Creek basin

[SMAX, maximum available water-holding capacity of the soil-zone reservoir in centimeters; $\mathrm{cm}$, centimeter]

\begin{tabular}{|c|c|c|c|c|c|}
\hline \multirow{2}{*}{$\begin{array}{l}\text { Water } \\
\text { year }\end{array}$} & \multirow{2}{*}{$\begin{array}{l}\text { Basin- } \\
\text { wide } \\
\text { precipi- } \\
\text { tation } \\
\text { (cm) }\end{array}$} & \multirow{2}{*}{$\begin{array}{c}\text { Ob- } \\
\text { served } \\
\text { runoff } \\
\text { (cm) }\end{array}$} & \multicolumn{3}{|c|}{$\begin{array}{l}\text { Simulated runoff }(\mathrm{cm}) \text { for } \\
\text { given values of SMAX }\end{array}$} \\
\hline & & & 1.27 & 2.54 & 3.81 \\
\hline 1987 & 55.63 & $35.81^{*}$ & 36.65 & 35.59 & 34.70 \\
\hline 1988 & 88.77 & 39.60 & 48.72 & 46.77 & 45.36 \\
\hline 1989 & 58.22 & 29.18 & 32.26 & 29.37 & 28.14 \\
\hline 1990 & 60.05 & 25.98 & 27.79 & 24.69 & 23.19 \\
\hline 1991 & 62.36 & 35.56 & 32.11 & 29.72 & 28.14 \\
\hline 1992 & 58.45 & 32.08 & 30.10 & 27.23 & 25.63 \\
\hline $\begin{array}{l}\text { Period } \\
\text { average }\end{array}$ & 63.91 & 33.05 & 34.62 & 32.23 & 30.86 \\
\hline
\end{tabular}

*Includes estimated runoff of $7.95 \mathrm{~cm}$ for the period October 1 through May 6.
Table 8. Simulated and observed snowpack water equivalents, East Stewart Creek basin

[cm, centimeter]

\begin{tabular}{lccc}
\hline \multirow{2}{*}{ Date } & $\begin{array}{c}\text { Simulated } \\
\text { basin-wide } \\
\text { snowpack } \\
\text { water } \\
\text { equivalent } \\
\text { (cm) }\end{array}$ & \multicolumn{2}{c}{$\begin{array}{c}\text { Snowpack water } \\
\text { equivalents }\end{array}$} \\
\cline { 3 - 4 } & 37.41 & $\begin{array}{c}\text { Lower } \\
\text { snow } \\
\text { course } \\
\text { (cm) }\end{array}$ & $\begin{array}{c}\text { Upper } \\
\text { snow } \\
\text { course } \\
\text { (cm) }\end{array}$ \\
\hline April 05, 1988 & 27.58 & 23.1 & 42.2 \\
February 22, 1989 & 9.60 & 23.4 & 27.7 \\
January 31, 1990 & 16.31 & 15.7 & 8.4 \\
April 03, 1990 & 5.56 & 7.9 & 18.8 \\
January 29, 1991 & 27.23 & 30.7 & 5.1 \\
February 19, 1992 & 31.45 & 25.7 & 40.9 \\
April 09, 1992 & & & 38.1 \\
\hline
\end{tabular}


Comparing information listed in table 7, for water year 1988, and in table 8, for the April 5, 1988, water equivalents, the DSCOR value of 1.3 may be inappropriate for 1987-88 snow season, and most likely it is too high. That is, the high amount of basinwide precipitation $(88.77 \mathrm{~cm})$ appears to be excessive in relation to the observed annual runoff of $39.60 \mathrm{~cm}$. Also, note the large discrepancy between observed and simulated runoff values for 1988 , on the order of 10 percent of basinwide precipitation. A value of DSCOR of about 1.2 would yield more realistic simulation results for this particular water year. A modification of this type was not considered appropriate because of the lack of onsite data on the spatial variability of precipitation, and other factors affecting snow accumulation and redistribution such as wind and drifting patterns.

The parameter SEP (table 2) controls the year-toyear amounts of basefiow contribution to simulated total annual streamflow, given that the characteristics
SMAX and DSCOR are fit to approximately balance the average annual water budget. A fitted value of SEP equal to $0.64 \mathrm{~cm} / \mathrm{d}$ was determined by trial and error adjustments made so as to match low-flow streamflow traces for the fall-winter periods of observed discharge data. Figures 11 and 12 illustrate the generally close correspondence between observed and simulated baseflow during recession periods (September through March).

A summary of PRMS simulation results is shown in table 9. The average potential evapotranspiration, PET, shows a much-reduced value in relation to the results presented for 3-Springs basin (table 6). Annual PET for 3-Springs basin averaged about $114 \mathrm{~cm}$ as compared to about $66 \mathrm{~cm}$ for East Stewart basin. The reduced magnitude of PET at East Stewart basin is directly related to differences in the temperature and solar radiation regimes as summarized in table 1. For example, the average solar radiation at

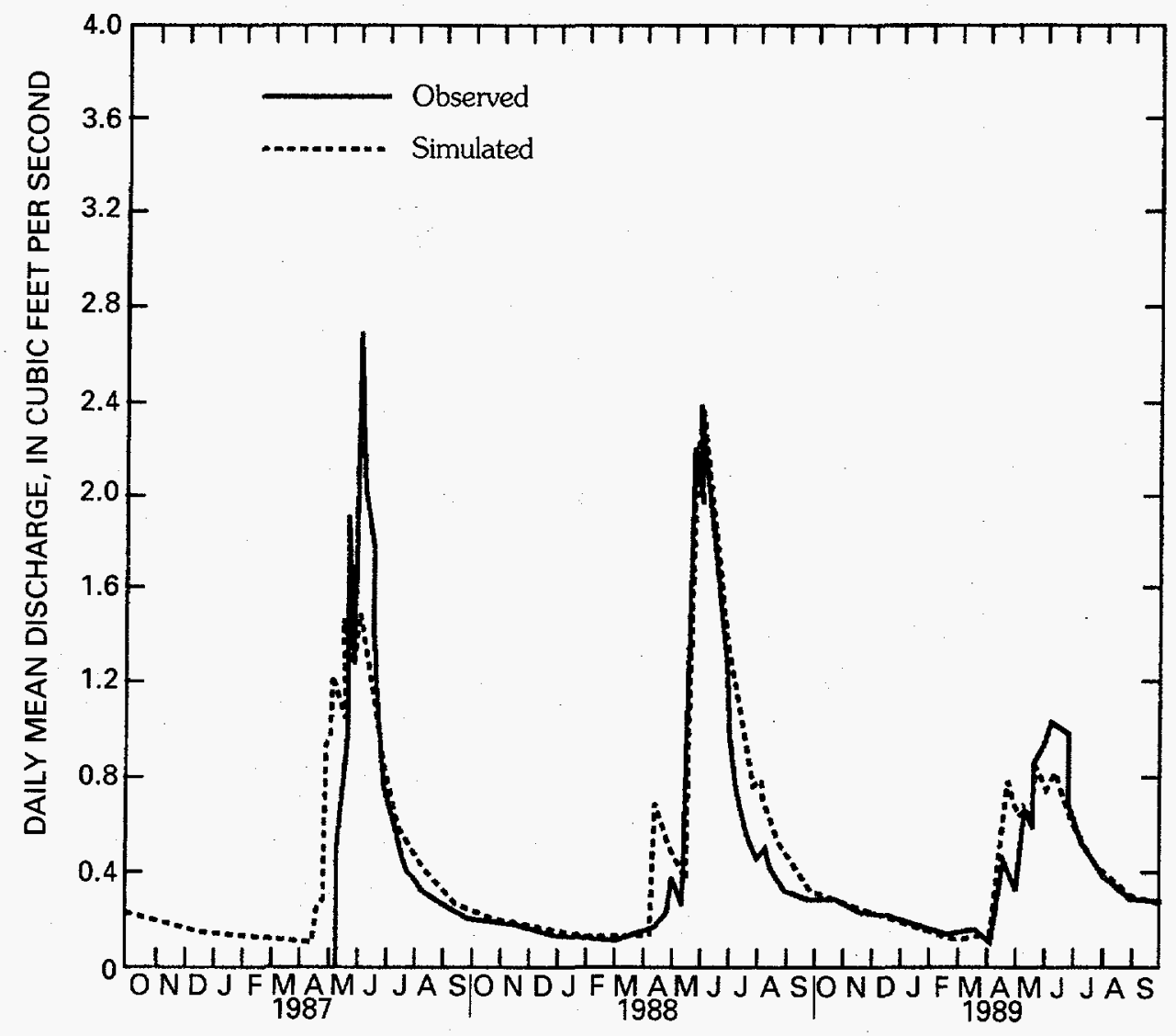

Figure 11. Observed and simulated daily-mean discharge for water years 1987 through 1989 of East Stewart Creek, Central Nevada. 
East Stewart basin is about 90 percent of that recorded at 3-Springs basin, and this, coupled with lower average daily temperatures, results in reduced PET at East Stewart basin.

Period-average values of the subsurface and ground-water reservoir components of simulated streamflow listed in table 9 are approximately equal in magnitude and dominate modeled results. Note that the year-to-year variability in the magnitude of the subsurface streamflow component greatly exceeds that of the ground-water component. For example, the subsurface component ranges from 9.01 to $29.57 \mathrm{~cm}$, while the ground-water component indicates a range of from 14.05 to $18.90 \mathrm{~cm}$. The sum of these two flow components indicates an average annual recharge to shallow and deep ground water of $32.15 \mathrm{~cm}$. This assessment assumes that negligible change in reservoir storage amounts occurred during the period, as is supported, by the magnitude of "Change in storage" indicated in table $9(-0.18 \mathrm{~cm})$. Observed average annual runoff for the 6-year period is $33.05 \mathrm{~cm}$.

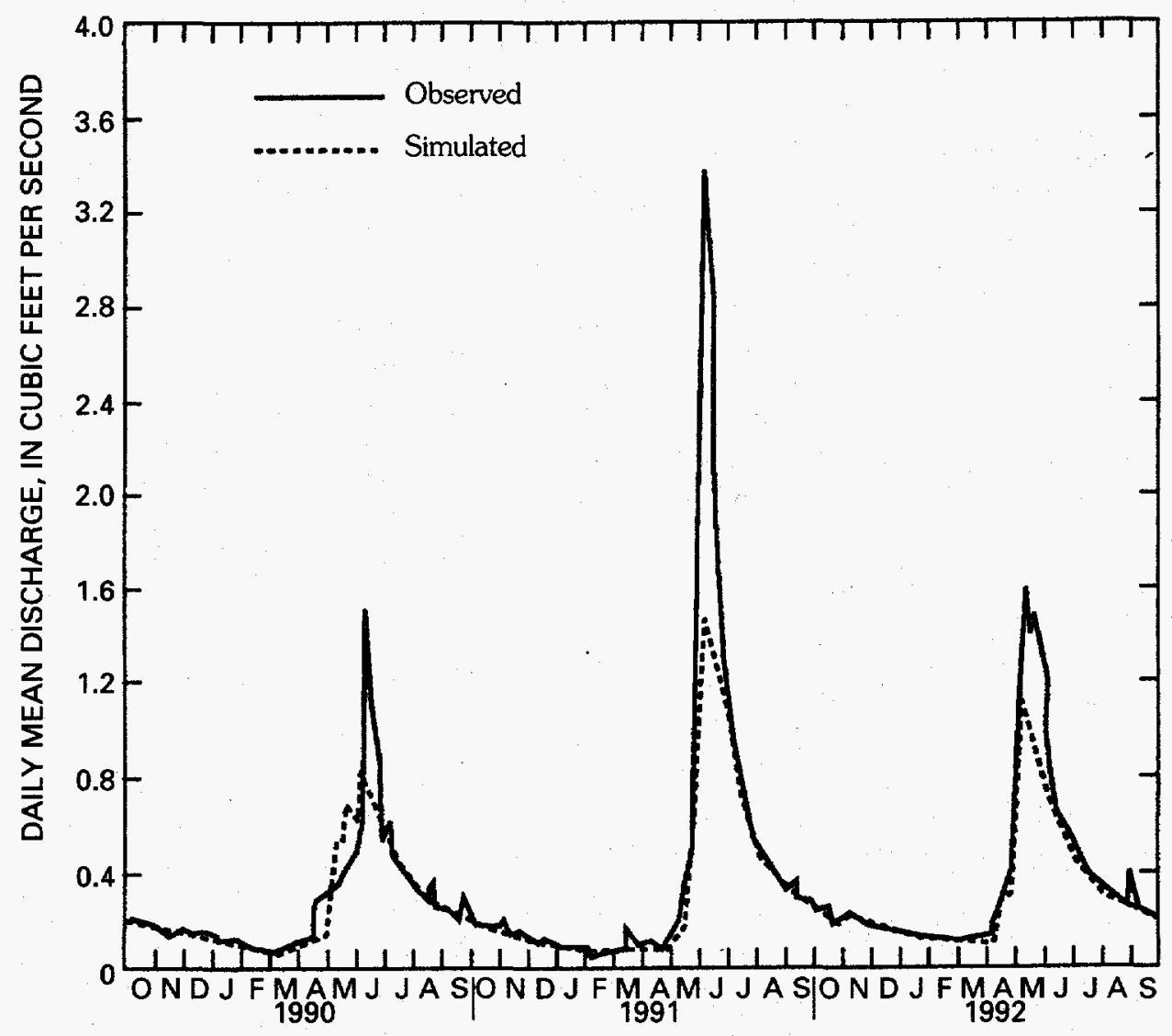

Figure 12. Observed and simulated daily-mean discharge for water years 1990 through 1992 of East Stewart Creek, Central Nevada. 
Table 9. Summary of simulation results for East Stewart Creek basin

[PPT, precipitation; PET, potential evapotranspiration; AET, actual evapotranspiration from canopy, snowpack, and soil zone; SAS, overland flow to stream; RAS, subsurface flow to stream; BAS, ground-water flow to stream; SUM, total simulated streamflow; OBS, observed streamflow; cm, centimeter]

\begin{tabular}{|c|c|c|c|c|c|c|c|c|c|}
\hline \multirow[b]{2}{*}{ Water year } & \multirow{2}{*}{$\begin{array}{l}\text { PPT } \\
(\mathrm{cm})\end{array}$} & \multirow{2}{*}{$\begin{array}{l}\text { PET } \\
(\mathrm{cm})\end{array}$} & \multirow{2}{*}{$\begin{array}{l}\text { AET } \\
(\mathrm{cm})\end{array}$} & \multirow{2}{*}{$\begin{array}{c}\text { Change } \\
\text { in storage } \\
\text { (cm) }\end{array}$} & \multicolumn{3}{|c|}{ Components of streamflow } & \multirow{2}{*}{$\begin{array}{l}\text { SUM } \\
(\mathrm{cm})\end{array}$} & \multirow{2}{*}{$\begin{array}{l}\text { OBS } \\
(\mathrm{cm})\end{array}$} \\
\hline & & & & & $\begin{array}{l}\text { SAS } \\
(\mathrm{cm})\end{array}$ & $\begin{array}{l}\text { RAS } \\
\text { (cm) }\end{array}$ & $\begin{array}{l}\text { BAS } \\
(\mathrm{cm})\end{array}$ & & \\
\hline 1987 & 55.63 & 68.12 & 20.65 & -0.61 & 0.03 & 18.39 & 17.17 & 35.59 & $35.81^{*}$ \\
\hline 1988 & 88.77 & 70.15 & 38.13 & 3.86 & 0.05 & 29.57 & 17.15 & 46.77 & 39.60 \\
\hline 1989 & 58.22 & 71.98 & 31.80 & -2.95 & 0.03 & 10.44 & 18.90 & 29.37 & 29.18 \\
\hline 1990 & 60.05 & 71.50 & 35.71 & -0.36 & 0.15 & 9.02 & 15.52 & 24.69 & 25.98 \\
\hline 1991 & 62.36 & 65.02 & 32.26 & 0.38 & 0.05 & 15.62 & 14.05 & 29.72 & 35.56 \\
\hline 1992 & 58.45 & 70.43 & 32.56 & -1.37 & 0.08 & 10.36 & 16.79 & 27.23 & 32.08 \\
\hline $\begin{array}{l}\text { Period } \\
\text { average }\end{array}$ & 63.91 & 69.55 & 31.85 & -0.18 & 0.08 & 15.57 & 16.58 & 32.23 & 33.05 \\
\hline
\end{tabular}

\section{APPLICATION OF CHLORIDE-ION MODEL TO ANALOG STUDY BASINS}

The application of the chloride-ion model to the study basins used identical hydrologic response unit configurations and snow-season precipitation amounts as was used in the PRMS simulations so as to establish a credible basis for comparison of results. As mentioned previously, the extrapolation of index-site estimates of snowpack sublimation, $E_{\mathrm{S}}$, to develop a basinwide accounting of available moisture $\left(\mathrm{N}_{\mathrm{i}}\right.$, of equation 10 ), is a straight-forward computational algorithm that requires no adjustment or fitting of model characteristics. The model is "calibrated" (so to speak) by the specification of HRU characteristics.

Results of the analyses of index-site data are presented in tables 10 and 12 . Table 10 lists measured data and results of computations using equations 7 and 9 for the index site at 3-Springs basin. Table 12 lists similar data and results for the two index sites at East Stewart basin (lower and upper index sites, fig. 3). The data and results listed in table 10 for 3-Springs basin indicate that the canister measurements of recharge, $R_{g}$, are inconsistent, and in 1988, exceeded the amount of snow-season precipitation. Also, in 1990, a barely measurable amount of percolate was recorded. It is obvious that the volumetric measurements of $R_{g}$ recorded at the 3-Springs basin index site are nonrepresentative and of little value, as negative water balances are computed for 1987, 1988, 1991, and 1992 (table 10). However, the chloride chemistry is much better behaved and yields estimates of sublimation losses and available moisture (table 10) that are rational.
Results of extrapolation of index-site estimates of $E_{s}$ to compute a basinwide accounting of available moisture using equation (10) are listed in table 11 for 3-Springs basin. The computed results listed under the column heading $\left(R_{g}+R_{g}\right)$ of table 11 are the results of interest and indicate an average annual value of available moisture of $16.61 \mathrm{~cm}$ for 3-Springs basin. Recall that PRMS application to 3-Springs basin required a fitted value of $15.24 \mathrm{~cm}$ for SMAX, the maximum available moisture storage of the soil zone. One of the assumptions of the chloride-ion model is that negligible change in soil-moisture storage occurs over a snowseason accounting period. This assumption is violated about $15 \mathrm{~cm}$ in the application of the method to 3-Springs basin. The algebraic difference between the basinwide estimate of average annual available moisture $(16.61 \mathrm{~cm})$ and the fitted value of SMAX $(15.24 \mathrm{~cm})$ is a fair approximation of the observed average annual runoff $(1.07 \mathrm{~cm})$.

The results listed in tables 12 and 13 pertain to East Stewart basin index sites and basinwide extrapolations. Again, as at 3-Springs basin, the measurements of percolate collected in the buried canisters are erratic and are of little value in assessing the relative magnitude of flow paths of available moisture $\left(R_{g}\right.$ and $R_{s}$ ). However, the results of extrapolation of index-site estimates of $E_{s}$ indicate rational patterns of variability in the computed values of annual basinwide available moisture. The highest observed annual runoff is associated with the highest annual evaluations of available moisture (1988, table 13). Similarly, the lowest observed annual runoff is associated with lowest annual values of available moisture (1990, table 13). 
Table 10. Water budget at index site, 3-Springs basin

[P, seasonal precipitation at index site (October I-May 31, about); $\mathrm{R}_{\mathrm{g}}$, measured percolate at index site (October 1-May 31 , about); [Cl $\left.{ }_{\mathrm{R}_{\mathrm{g}}}\right]$, chloride-ion concentration in percolate; $\left[\mathrm{Cl}_{\mathrm{p}}\right]$, chloride ion concentration in precipitation; $\mathrm{E}_{\mathrm{s}}$, evaporation/sublimation from snowpack at index site, equation $9 ;\left(R_{g}+R_{s}\right)$, available moisture at index site, equation $7 ; \mathrm{cm}$, centimeter; $\mu \mathrm{mol} / \mathrm{cm}^{-3}$, micromole per cubic centimeter]

\begin{tabular}{|c|c|c|c|c|c|c|c|}
\hline \multirow[b]{2}{*}{ Water year } & \multicolumn{4}{|c|}{ Measured variables at index site } & \multicolumn{3}{|c|}{ Computed results, equations 7,9} \\
\hline & $\begin{array}{c}P \\
(\mathrm{~cm})\end{array}$ & $\begin{array}{c}R_{\mathbf{g}} \\
(\mathbf{c m})\end{array}$ & $\underset{\mu \mathrm{mol} / \mathrm{cm}^{-3}}{\left[\mathrm{Cl}_{\mathrm{Rg}}\right]}$ & $\begin{array}{c}{\left[\mathrm{Cl}_{\mathrm{p}}\right]} \\
\mu \mathrm{mol} / \mathrm{cm}^{-3}\end{array}$ & $\begin{array}{c}E_{s} \\
(\mathrm{~cm})\end{array}$ & $\begin{array}{c}R_{\mathrm{s}} \\
(\mathrm{cm})\end{array}$ & $\begin{array}{c}\left(R_{\mathrm{g}}+R_{s}\right) \\
(\mathrm{cm})\end{array}$ \\
\hline 1987 & 22.56 & 15.44 & 0.0874 & 0.01080 & 19.76 & -12.64 & 2.80 \\
\hline 1988 & 35.33 & 45.82 & 0.0344 & 0.00846 & 26.64 & -37.13 & 8.69 \\
\hline 1989 & 18.69 & 0.71 & 0.0725 & 0.01880 & 13.82 & 4.16 & 4.87 \\
\hline 1990 & 20.32 & 0.08 & 0.1440 & 0.01180 & 18.67 & 1.57 & 1.63 \\
\hline 1991 & 23.55 & 15.88 & 0.0592 & 0.01350 & 18.19 & -10.51 & 5.37 \\
\hline 1992 & 24.69 & 15.39 & 0.1100 & 0.00395 & 23.80 & -14.50 & 0.89 \\
\hline
\end{tabular}

Table 11. Extrapolation of index-site data to 3-Springs basin

$\left[P\right.$, seasonal precipitation at index site (October 1-May 31, about); $E_{s}$, evaporation/sublimation from snowpack at index site; $\left(R_{g}+R_{s}\right)$, available moisture at index site; $\mathrm{P}^{\prime}$, basin-wide seasonal precipitation (October 1-May 31, about); $\mathrm{E}^{\prime}$, basinwide evaporation/sublimation from canopy and snowpack; $\left(R_{g}+R_{s}\right)$, basinwide available moisture; OBS, observed seasonal runoff; $\mathrm{cm}$, centimeter]

\begin{tabular}{|c|c|c|c|c|c|c|c|}
\hline \multirow[b]{2}{*}{ Water year } & \multicolumn{3}{|c|}{ Index site } & \multicolumn{3}{|c|}{ Basin-wide extrapolation } & \multirow{2}{*}{$\begin{array}{l}\text { OBS } \\
\text { (cm) }\end{array}$} \\
\hline & $\begin{array}{c}P \\
(\mathrm{~cm})\end{array}$ & $\begin{array}{c}E_{3} \\
(\mathrm{~cm})\end{array}$ & $\begin{array}{c}\left(\mathbf{R}_{\mathrm{g}}+\mathbf{R}_{\mathbf{s}}\right) \\
(\mathrm{cm})\end{array}$ & $\begin{array}{c}P^{\prime} \\
\text { (cm) }\end{array}$ & $\begin{array}{c}E_{s}^{\prime} \\
(\mathrm{cm})\end{array}$ & $\underset{(\mathrm{cm})}{\left(R_{\mathrm{g}}+R_{\mathrm{g}}\right)^{\prime}}$ & \\
\hline 1987 & 22.56 & 19.76 & 2.80 & 26.67 & 11.46 & 15.21 & $0 . \overline{46}$ \\
\hline 1988 & 35.33 & 26.64 & 8.69 & 41.76 & 16.71 & 25.05 & 4.67 \\
\hline 1989 & 18.69 & 13.82 & 4.87 & 22.10 & 8.76 & 13.34 & 0.03 \\
\hline 1990 & 20.32 & 18.67 & 1.63 & 24.00 & 10.54 & 13.46 & 0.00 \\
\hline 1991 & 23.55 & 18.19 & 5.37 & 27.84 & 11.25 & 16.59 & 0.10 \\
\hline 1992 & 24.69 & 23.80 & 0.89 & 29.18 & 13.13 & 16.05 & 1.09 \\
\hline Period average & 24.18 & 20.14 & 4.04 & 28.60 & 11.98 & 16.62 & 1.07 \\
\hline
\end{tabular}


Table 12. Water budgets at lower and upper index sites, East Stewart Creek basin

[P, seasonal precipitation at index site (September 15-June 15 , about); $\mathrm{R}_{\mathrm{g}}$, measured percolate at index site (September 15-June 15, about); [Cl $\left.\mathrm{R}_{\mathrm{g}}\right]$, chlorideion concentration in percolate; $\left[\mathrm{Cl}_{\mathrm{p}}\right]$, chloride-ion concentration in precipitation at a single sampling site; $\mathrm{E}_{\boldsymbol{s}}$, evaporation/sublimation from snowpack at index site, equation $9 ;\left(R_{g}+R_{s}\right)$, available moisture at index site, equation $7 ; \mathrm{cm}$, centimeter; $\mu \mathrm{mol} / \mathrm{cm}^{-3}$, micromole per cubic centimeter]

\begin{tabular}{|c|c|c|c|c|c|c|c|}
\hline \multirow[b]{2}{*}{ Water year } & \multicolumn{4}{|c|}{ Measured at lower index site } & \multicolumn{3}{|c|}{ Computed results, equations 7,9} \\
\hline & $\begin{array}{c}P \\
(\mathrm{~cm})\end{array}$ & $\begin{array}{c}R_{\mathrm{g}} \\
(\mathrm{cm})\end{array}$ & $\underset{\mu \mathrm{mol} / \mathrm{cm}^{-3}}{\left[\mathrm{Cl}_{\mathrm{Rg}}\right]}$ & $\underset{\mu \mathrm{mol} / \mathrm{cm}^{-3}}{\left[\mathrm{Cl}_{\mathrm{p}}\right]}$ & $\begin{array}{c}E_{\mathrm{g}} \\
(\mathrm{cm})\end{array}$ & $\begin{array}{c}R_{s} \\
(\mathrm{~cm})\end{array}$ & $\begin{array}{c}\left(R_{\mathrm{g}}+R_{\mathrm{s}}\right) \\
(\mathrm{cm})\end{array}$ \\
\hline 1987 & 58.75 & 18.47 & 0.0254 & 0.00649 & 43.74 & -3.46 & 15.01 \\
\hline 1988 & 64.80 & 2.03 & 0.0592 & 0.01330 & 50.24 & 12.53 & 14.56 \\
\hline 1989 & 50.90 & 0.15 & 0.1830 & 0.01380 & 47.07 & 3.68 & 3.83 \\
\hline 1990 & 46.74 & 0.08 & 0.5080 & 0.01240 & 45.59 & 1.07 & 1.15 \\
\hline 1991 & 57.73 & 0.10 & 0.0564 & 0.01100 & 46.48 & 11.15 & 11.25 \\
\hline \multirow[t]{2}{*}{1992} & 49.20 & 0.48 & 0.0395 & 0.01070 & 35.86 & 12.86 & 13.34 \\
\hline & \multicolumn{4}{|c|}{ Measured at upper index site } & \multicolumn{3}{|c|}{ Computed results, equations 7,9} \\
\hline Water year & $\begin{array}{c}P \\
(\mathrm{~cm})\end{array}$ & $\begin{array}{c}R_{g} \\
(\mathrm{~cm})\end{array}$ & $\underset{\mu \mathrm{mol} / \mathrm{cm}^{-3}}{\left[\mathrm{Cl}_{\mathrm{Rg}}\right]}$ & $\begin{array}{c}{\left[\mathrm{Cl}_{p}\right]} \\
\mu \mathrm{mol} / \mathrm{cm}^{-3}\end{array}$ & $\begin{array}{c}E_{8} \\
(\mathrm{~cm})\end{array}$ & $\begin{array}{c}\mathbf{A}_{\mathbf{s}} \\
(\mathrm{cm})\end{array}$ & $\begin{array}{c}\left(R_{\mathrm{g}}+\mathbf{R}_{\mathrm{s}}\right) \\
(\mathrm{cm})\end{array}$ \\
\hline 1988 & 83.44 & 5.13 & 0.0195 & 0.01330 & 26.52 & 51.79 & 56.92 \\
\hline 1989 & 53.06 & 0.13 & 0.2000 & 0.01380 & 49.40 & 3.53 & 3.66 \\
\hline 1990 & 46.99 & 0.86 & 0.0790 & 0.01240 & 39.62 & 6.51 & 7.37 \\
\hline 1991 & 57.18 & 2.16 & 0.0223 & 0.01100 & 28.98 & 26.05 & 28.21 \\
\hline 1992 & 50.72 & 14.20 & 0.0130 & 0.01070 & 8.97 & 27.55 & 41.75 \\
\hline
\end{tabular}

Table 13. Extrapolation of index-site data to East Stewart Creek basin

$\left[P\right.$, seasonal precipitation at index site (September 15-June 1S, about); $E_{s}$, evaporation/sublimation from snowpack at index site; $\left(R_{g}+R_{s}\right)$, available moisture at index site; $P^{\prime}$, basinwide seasonal precipitation (September 15-June 15, about); $E_{s}$, basinwide evaporation/sublimation from canopy and snowpack; $\left(R_{g}+R_{s}\right)$, basinwide available moisture; OBS, observed seasonal runoff (March 1-February 28, 29); cm, centimeter]

\begin{tabular}{|c|c|c|c|c|c|c|c|}
\hline \multirow[b]{2}{*}{ Water year } & \multicolumn{3}{|c|}{ Lower index site } & \multicolumn{4}{|c|}{ Basinwide extrapolation. } \\
\hline & $\begin{array}{c}P \\
(\mathrm{~cm})\end{array}$ & $\begin{array}{c}E_{s} \\
(\mathbf{c m})\end{array}$ & $\begin{array}{c}\left(\mathbf{R}_{\mathbf{g}}+\mathbf{R}_{\mathbf{s}}\right) \\
(\mathrm{cm})\end{array}$ & $\begin{array}{c}P^{\prime} \\
(\mathrm{cm})\end{array}$ & $\begin{array}{c}E_{8}^{\prime} \\
(\mathrm{cm})\end{array}$ & $\begin{array}{c}\left(\mathbf{R}_{\mathrm{g}}+\mathbf{R}_{\mathrm{s}}\right)^{\prime} \\
(\mathrm{cm})\end{array}$ & $\begin{array}{l}\text { OBS } \\
(\mathrm{cm})\end{array}$ \\
\hline 1987 & 58.75 & 43.74 & 15.01 & 55.60 & 30.99 & 24.61 & 35.00 \\
\hline 1988 & 64.80 & 50.24 & 14.56 & 79.58 & 37.92 & 41.66 & 41.71 \\
\hline 1989 & 50.90 & 47.07 & 3.83 & 52.60 & 32.05 & 20.55 & 28.22 \\
\hline 1990 & 46.74 & 45.59 & 1.15 & 46.94 & 30.38 & 16.56 & 24.84 \\
\hline 1991 & 57.73 & 46.48 & 11.25 & 57.30 & 32.59 & 24.71 & 37.52 \\
\hline 1992 & 49.20 & 35.86 & 13.34 & 50.42 & 26.16 & 24.26 & 30.20 \\
\hline Period average & 54.69 & 44.83 & 9.86 & 57.07 & 31.67 & 25.37 & 32.92 \\
\hline \multirow[b]{2}{*}{ Water year } & \multicolumn{3}{|c|}{ Upper index site } & \multicolumn{4}{|c|}{ Basinwide extrapolation } \\
\hline & $\begin{array}{c}P \\
(\mathrm{~cm})\end{array}$ & $\begin{array}{c}E_{s} \\
(\mathrm{~cm})\end{array}$ & $\begin{array}{c}\left(R_{g}+R_{s}\right) \\
(\mathrm{cm})\end{array}$ & $\begin{array}{c}P^{\prime} \\
(\mathrm{cm})\end{array}$ & $\begin{array}{c}E_{s}^{\prime} \\
(\mathrm{cm})\end{array}$ & $\begin{array}{c}\left(\mathbf{R}_{\mathbf{g}}+\mathbf{R}_{\mathbf{s}}\right)^{\prime} \\
(\mathrm{cm})\end{array}$ & $\begin{array}{l}\text { OBS } \\
(\mathrm{cm})\end{array}$ \\
\hline 1988 & 83.44 & 26.52 & 56.92 & 79.58 & 25.27 & 54.30 & 41.71 \\
\hline 1989 & 53.06 & 49.40 & 3.66 & 52.60 & 31.60 & 21.00 & 28.22 \\
\hline 1990 & 46.99 & 39.62 & 7.37 & 46.94 & 26.16 & 20.78 & 24.84 \\
\hline 1991 & 57.18 & 28.98 & 28.21 & 57.30 & 22.96 & 34.34 & 37.52 \\
\hline 1992 & 50.72 & 8.97 & 41.75 & 50.42 & 12.52 & 37.90 & 30.20 \\
\hline Period average & 58.27 & 30.68 & 27.59 & 57.35 & 23.70 & 33.66 & 32.49 \\
\hline
\end{tabular}


The computed amounts of available moisture using the lower index-site extrapolations are consistently less than those computed using upper index-site data. Compare for example, the period-average values of 25.37 and $33.66 \mathrm{~cm}$. The deviation of about $8 \mathrm{~cm}$ is not excessive and could easily be removed by a 10-percent reduction in the $\mathrm{E}_{\mathrm{s}}$ values at the lower site, coupled with a 10-percent increase in $E_{s}$ at the upper site. Overall, the results of extrapolation could be judged as informative and only slightly biased. The low value of maximum available soil-moisture storage (SMAX $=2.54 \mathrm{~cm}$ ), as indicated from PRMS fitting, is the reason East Stewart basinwide computations of available moisture show a closer relation to observed runoff amounts than those for 3-Springs basin.

\section{REDUCED FORM OF THE CHLORIDE-ION MODEL}

The use of chloride-ion concentrations in precipitation inputs and those measured in water samples of streamflow offers an alternative approach to the indexsite extrapolation procedure to assess basinwide, average-annual evapotranspiration and sublimation losses $\left(E_{t}+E_{s}\right)$, and available moisture $\left(R_{g}+R_{s}\right)$ (equation 1 ). This potential application of the interrelation of chloride-ion water chemistry was suggested in Claassen and others (1986). The reduced form of the chlorideion model cannot yield estimates of the magnitudes of the individual runoff components $R_{g}$ and $R_{s}$ because there is no direct evaluation of either component as in the index-site extrapolation approach. In addition, it would be difficult to attempt an annual evaluation of the lumped components (that is, $E_{t}+E_{s}$, and $R_{g}+R_{s}$ ) and therefore, time-averaged data are used in the following analysis.
Listed in table 14 are the results of the reduced, time-average approach to estimate available moisture using average annual basinwide precipitation, and average values of chloride-ion concentration in precipitation and streamflow for water years 1987 through 1992. The concentration values listed for precipitation are the result of a volume-weighted computation that integrates the total mass of chloride over the time interval. The concentration values for streamflow are a simple average of the data available from grab samples collected at or near the streamflow-gaging sites. The computed results listed in table 14 are derived from a slight modification of equation 9 as

$$
\mathrm{E}_{\mathrm{t}}+\mathrm{E}_{\mathrm{s}}=\mathrm{P}\left\{1-\left[\mathrm{Cl}_{\mathrm{p}}\right] /\left[\mathrm{Cl}_{\mathrm{sf}}\right]\right\}
$$

where the sum $E_{t}+E_{s}$ represents total average annual losses, $\mathrm{P}$ is average annual basinwide precipitation, $\left[\mathrm{Cl}_{\mathrm{p}}\right]$ is average chloride-ion concentration in precipitation, and $\left[\mathrm{Cl}_{\mathrm{sf}}\right]$ is average concentration of water samples of streamflow (the variability of chloride-ion concentration in streamflow samples is low, with coefficient of variation of about 15 percent).

The values of available moisture shown in table 14 (column heading $R_{g}+R_{s}$ ) are approximately the same magnitude as observed estimates of average annual runoff, and also the values indicated by PRMS simulation results. A compilation of the results of the PRMS and two versions of the chloride ion are shown in table 15. As mentioned previously, the excessive value of estimated recharge derived from the index-site extrapolation procedure for 3-Springs basin is due to the storage and subsequent evapotranspiration of about $15 \mathrm{~cm}$ of water from the soil zone.

Table 14. Average annual losses $\left(E_{t}+E_{s}\right)$, and available moisture $\left(R_{g}+R_{s}\right)$ for the analog study basins $\left[\mathrm{cm}\right.$, centimeter; $\mu \mathrm{mol} / \mathrm{cm}^{-3}$, micromole per cubic centimeter $]$

\begin{tabular}{|c|c|c|c|c|c|}
\hline \multirow[b]{2}{*}{ Basin } & \multirow{2}{*}{$\begin{array}{l}\text { Average annual basin- } \\
\text { wide precipitation } \\
\text { (cm) }\end{array}$} & \multicolumn{2}{|c|}{ Average chloride concentration } & \multicolumn{2}{|c|}{ Computed results } \\
\hline & & $\begin{array}{c}\text { In precipitation } \\
\left(\mu \mathrm{mol} / \mathrm{cm}^{-3}\right)\end{array}$ & $\begin{array}{c}\text { In streamflow } \\
\left(\mu \mathrm{mol} / \mathrm{cm}^{-3}\right)\end{array}$ & $\begin{array}{c}\left(E_{t}+E_{s}\right) \\
(\mathrm{cm})\end{array}$ & $\begin{array}{c}\left(R_{\mathrm{g}}+\mathbf{R}_{\mathrm{s}}\right) \\
(\mathrm{cm})\end{array}$ \\
\hline 3-Springs & 33.63 & 0.0101 & 0.1040 & 30.35 & 3.28 \\
\hline East Stewart & 63.91 & 0.0112 & 0.0231 & 32.92 & 30.99 \\
\hline
\end{tabular}


Table 15. Compilation of observed data and model estimates of average annual recharge for study basins

[cm, centimeter; PRMS, precipitation-runoff modeling system]

\begin{tabular}{|c|c|c|c|c|c|}
\hline \multirow[b]{2}{*}{ Basin } & \multicolumn{2}{|c|}{ Average annual values of } & \multicolumn{3}{|c|}{ Model estimates of average annual recharge } \\
\hline & $\begin{array}{l}\text { Basin-wide } \\
\text { precipitation } \\
\text { (cm) }\end{array}$ & $\begin{array}{c}\text { Observed } \\
\text { runoff } \\
\text { (cm) }\end{array}$ & $\begin{array}{c}\text { PRMS } \\
\text { (cm) }\end{array}$ & $\begin{array}{l}\text { Index-site } \\
\text { extrapolation } \\
\text { (cm) }\end{array}$ & $\begin{array}{c}\text { Reduced } \\
\text { chloride-ion } \\
\text { model, eq (11) } \\
\text { (cm) }\end{array}$ \\
\hline 3-Springs & 33.63 & 1.07 & 1.14 & 16.62 & 3.28 \\
\hline East Stewart & 63.91 & 33.05 & 32.16 & $29.51^{*}$ & 30.99 \\
\hline
\end{tabular}

\section{SUMMARY AND CONCLUSIONS}

The results of the application of PRMS to model the land phase of the hydrologic cycle for two diverse, high-altitude basins in central Nevada reaffirms the general utility of the system, given that an adequate base of data is available. The required data base is extensive in comparison to that required for the application of either the index-site, chloride-ion modeling approach (extrapolation via equation 10 ), or the reduced chloride-ion model (time-averaged data via equation 11). However, the detail of inquiry afforded by PRMS exceeds that available from either of the chloride-ion models. For example, a complete timeseries evaluation of water-balance elements is available for analysis from PRMS output. However, if such detailed analysis and evaluation of time-series information is not of primary concern, then a modeling approach requiring less extensive data would be justified. The reduced chloride-ion model satisfies this later scenario.

It is concluded that the modeling approaches yield reasonably consistent and accurate estimates of average-annual recharge to ground water in these two diverse hydrologic settings. Average-annual values of modeled recharge range from about 1 to $3 \mathrm{~cm} / \mathrm{yr}$ for 3-Springs basin. Comparable results for East Stewart Creek basin range from about 30 to $32 \mathrm{~cm} / \mathrm{yr}$. The most reliable results are those derived from the reduced chloride-ion model because they reflect integrated basin-wide processes in terms of only three measured variables, precipitation amount, precipitation chemistry, and streamflow chemistry.

\section{REFERENCES CITED}

Anderson, E.A., 1973, National Weather Service river forecast system-snow accumulation and ablation model: U.S. Department of Commerce, NOAA, Technical Memorandum NWS HYDRO-17, 217 p. [Available only from the National Technical Information Service, Springfield, VA 22161, acquisition no. COM-7410728.]

Claassen, H.C., Reddy, M.M., and Halm, D.R., 1986, Use of the chloride ion in determining hydrologic-basin water budgets-A 3-year case study in the San Juan Mountains, Colorado, U.S.A.: Journal of Hydrology, no. 85, p. 49-71.

Dickinson, W.T., and Whiteley, H.Q., 1970, Watershed areas contributing to runoff: International Association of Hydrologic Sciences Publication 96, p. 1.12-1.28.

Hewlett, J.D., and Nutter, W.L., 1970, The varying source area of streamflow from upland basins, in Symposium on Interdisciplinary Aspects of Watershed Management, Montana State University, Bozeman, Montana, 1970, Proceedings, p. 65-83.

Jensen, M.E., and Haise, H.R., 1963, Estimating evapotranspiration from solar radiation: Proceedings of the American Society of Civil Engineers, Journal of Irrigation and Drainage, v. 89, no. IR4, p. 15-41.

Leavesley, G.H., Lichty, R.W., Troutman, B.M., and Saindon, L.G., 1983, Precipitation-runoff modeling system-User's manual: U.S. Geological Survey Water-Resources Investigations Report 83-4238, 207 p.

Linsley, R.K., Jr., Kohler, M.A., and Paulhus, J.L.H., 1958, Hydrology for engineers: McGraw-Hill, New York, $340 \mathrm{p}$.

McKinley, P.W., and Oliver, Thomas, 1994, Meteorological, discharge, and water-quality data from two small basins in central Nevada: U.S. Geological Survey Open-File Report 93-651, 167 p. 
McKinley, P.W., and Oliver, Thomas, 1995, Meteorological, stream-discharge, and water-quality data for water year 1992 from two small basins in central Nevada: U.S. Geological Survey Open-File Report 94-456, $56 \mathrm{p}$. (MOL.19950124.0284)

Obled, C., and Rosse, B.B., 1977, Mathematical models of a melting snowpack at an index plot: Journal of Hydrology, no. 31/32, p. 139-163.

Parker, R.S., and Norris, J.M., 1989, Simulation of streamflow in small drainage basins in the southern Yampa River Basin, Colorado: U.S. Geological Survey WaterResources Investigations Report 88-4071, 47 p.

Satterlund, D.R., 1972, Wildland watershed management: Wiley, New York, $370 \mathrm{p}$.

Satterlund, D.R., and Adams, P.W., 1992, Wildland watershed management-second edition: Wiley, New York, $436 \mathrm{p}$.
Swift, L.W., Jr., 1976, Algorithm for solar radiation on mountain slopes: Water Resources Research, v. 12, no. 1, p. $108-112$.

U.S. Army, 1956, Snow hydrology: Portland, Oreg., U.S. Army Corps of Engineers, North Pacific Division, $437 \mathrm{p}$.

U.S. Department of Commerce, 1982, Evaporation atlas for the contiguous 48 United States: National Oceanic and Atmospheric Administration Technical Report NWS 33, $26 \mathrm{p}$.

Wilm, H.G., and Dunford, E.G., 1948, Effect of timber cutting on water available for streamflow from a lodgepole pine forest: U.S. Department of Agriculture Technical Bulletin 968, 43 p.

Zahner, R., 1967, Refinement in empirical functions for realistic soil-moisture regimes under forest cover, in Sopper, W.E., and Lull, H.W., eds., International symposium of forest hydrology: New York, Pergamon Press, p. 261-274. 



\section{APPENDIX A.}

Hydrologic response unit characteristics for 3-Springs basin

\begin{tabular}{|c|c|c|c|c|c|c|c|}
\hline $\begin{array}{l}\text { Hydrologic } \\
\text { response unit } \\
\text { number }\end{array}$ & $\begin{array}{c}\text { Area } \\
\text { (hectares) }\end{array}$ & $\begin{array}{c}\text { Slope } \\
\text { (percent) }\end{array}$ & $\begin{array}{c}\text { Aspect } \\
\text { (degree) }\end{array}$ & $\begin{array}{l}\text { Altitude } \\
\text { (meter) }\end{array}$ & $\begin{array}{c}\text { Canopy cover } \\
\text { density } \\
\text { (percent) }\end{array}$ & $\begin{array}{c}\text { Transmission } \\
\text { coefficient } \\
\text { (percent) }\end{array}$ & $\begin{array}{c}\text { Snow } \\
\text { correction } \\
\text { factor }\end{array}$ \\
\hline 1 & 8.5 & 39 & 315 & 2,230 & 50 & 25 & 1.04 \\
\hline 2 & 12.7 & 51 & 310 & 2,345 & 80 & 15 & 1.10 \\
\hline 3 & 5.4 & 40 & 0 & 2,500 & 40 & 33 & 1.17 \\
\hline 4 & 7.2 & 42 & 165 & 2,220 & 30 & 43 & 1.03 \\
\hline 5 & 11.4 & 32 & 33 & 2,220 & 50 & 25 & 1.03 \\
\hline 6 & 9.5 & 60 & 55 & 2,345 & 50 & 25 & 1.10 \\
\hline 7 & 13.4 & 60 & 70 & 2,315 & 40 & 33 & 1.08 \\
\hline 8 & 9.5 & 55 & 90 & 2,375 & 40 & 33 & 1.11 \\
\hline 9 & 9.6 & 55 & 20 & 2,375 & 40 & 33 & 1.11 \\
\hline 10 & 16.0 & 76 & 80 & 2,560 & 40 & 33 & 1.20 \\
\hline 11 & 5.8 & 93 & 75 & 2,680 & 30 & 43 & $1: 26$ \\
\hline 12 & 8.3 & 57 & 180 & 2,270 & 30 & 43 & 1.06 \\
\hline 13 & 6.8 & 78 & 330 & 2,330 & 60 & 18 & 1.09 \\
\hline 14 & 6.6 & 75 & 355 & 2,500 & 60 & 18 & 1.17 \\
\hline 15 & 9.3 & 68 & 335 & 2,610 & 40 & 33 & 1.23 \\
\hline 16 & 10.0 & 80 & 55 & 2,635 & 40 & 33 & 1.24 \\
\hline 17 & 12.9 & 64 & 180 & 2,605 & 30 & 43 & 1.23 \\
\hline 18 & 13.5 & 59 & 80 & 2,415 & 30 & 43 & 1.13 \\
\hline 19 & 13.6 & 71 & 80 & 2,560 & 30 & 43 & 1.20 \\
\hline 20 & 4.7 & 73 & 25 & 2,355 & 30 & 43 & 1.10 \\
\hline 21 & 5.4 & 73 & 10 & 2,530 & 40 & 33 & 1.19 \\
\hline 22 & 7.7 & 64 & 45 & 2,680 & 40 & 33 & 1.26 \\
\hline 23 & 5.7 & 57 & 220 & 2,440 & 40 & 33 & 1.14 \\
\hline 24 & 14.4 & 54 & 45 & 2,440 & 30 & 43 & 1.14 \\
\hline 25 & 8.6 & 54 & 0 & 2,620 & 40 & 33 & 1.23 \\
\hline 26 & 7.0 & 50 & 25 & 2,745 & 15 & 65 & 1.30 \\
\hline 27 & 6.8 & 55 & 150 & 2,440 & 30 & 43 & 1.14 \\
\hline 28 & 13.6 & 55 & 180 & 2,500 & 20 & 57 & 1.17 \\
\hline 29 & 11.5 & 50 & 0 & 2,530 & 30 & 43 & 1.19 \\
\hline 30 & 8.9 & 55 & 190 & 2,560 & 15 & 65 & 1.20 \\
\hline 31 & 7.0 & 64 & 5 & 2,720 & 20 & 57 & 1.28 \\
\hline 32 & 5.8 & 64 & 160 & 2,585 & 10 & 75 & 1.22 \\
\hline 33 & 6.7 & 66 & 20 & 2,530 & 40 & 33 & 1.19 \\
\hline 34 & 5.4 & 70 & 80 & 2,510 & 30 & 43 & 1.18 \\
\hline 35 & 5.7 & 30 & 45 & 2,710 & 30 & 43 & 1.28 \\
\hline
\end{tabular}


Hydrologic response unit characteristics for 3-Springs basin--Continued

\begin{tabular}{|c|c|c|c|c|c|c|c|}
\hline $\begin{array}{l}\text { Hydrologic } \\
\text { response unit } \\
\text { number }\end{array}$ & $\begin{array}{c}\text { Area } \\
\text { (hectares) }\end{array}$ & $\begin{array}{c}\text { Slope } \\
\text { (percent) }\end{array}$ & $\begin{array}{c}\text { Aspect } \\
\text { (degree) }\end{array}$ & $\begin{array}{l}\text { Altitude } \\
\text { (meter) }\end{array}$ & $\begin{array}{c}\text { Canopy cover } \\
\text { density } \\
\text { (percent) }\end{array}$ & $\begin{array}{c}\text { Transmission } \\
\text { coefficient } \\
\text { (percent) }\end{array}$ & $\begin{array}{c}\text { Snow } \\
\text { correction } \\
\text { factor }\end{array}$ \\
\hline 36 & 3.9 & 70 & 230 & 2,595 & 10 & 75 & 1.22 \\
\hline 37 & 5.1 & 46 & 100 & 2,560 & 50 & 25 & 1.20 \\
\hline 38 & 8.2 & 45 & 70 & 2,535 & 15 & 65 & 1.19 \\
\hline 39 & 11.0 & 28 & 40 & 2,705 & 15 & 65 & 1.28 \\
\hline 40 & 9.6 & 30 & 40 & 2,805 & 40 & 33 & 1.33 \\
\hline 41 & 4.7 & 57 & 185 & 2,620 & 50 & 25 & 1.23 \\
\hline 42 & 5.9 & 64 & 155 & 2,800 & 0 & 100 & 1.32 \\
\hline 43 & 11.5 & 57 & 165 & 2,670 & 50 & 25 & 1.26 \\
\hline 44 & 10.9 & 60 & 90 & 2,695 & 40 & 33 & 1.27 \\
\hline 45 & 9.4 & 57 & 130 & 2,715 & 50 & 25 & 1.28 \\
\hline 46 & 9.3 & 56 & 80 & 2,620 & 50 & 25 & 1.23 \\
\hline 47 & 2.5 & 55 & 90 & 2,775 & 0 & 100 & 1.31 \\
\hline 48 & 3.2 & 34 & 90 & 2,470 & 95 & 10 & 1.16 \\
\hline 49 & 6.4 & 38 & 45 & 2,345 & 95 & 10 & 1.10 \\
\hline 50 & 3.2 & 13 & 100 & 2,315 & 95 & 10 & 1.09 \\
\hline
\end{tabular}

Generic parameters common to all HRU's:

Maximum daily snowmelt infiltration capacity, SRX

Maximum daily recharge to ground-water reservoir, SEP

Subsurface reservoir routing coefficient, RCF

Ground-water reservoir routing coefficient, $\mathrm{RCB}$
$5.08 \mathrm{~cm} / \mathrm{d}$

$0.25 \mathrm{~cm} / \mathrm{d}$

0.0910

0.0058 


\section{APPENDIX B.}

Hydrologic response unit characteristics for East Stewart Creek basin

\begin{tabular}{cccccccc}
\hline $\begin{array}{c}\text { Hydrologic } \\
\text { responseu } \\
\text { number }\end{array}$ & $\begin{array}{c}\text { Area } \\
\text { (hectares) }\end{array}$ & $\begin{array}{c}\text { Slope } \\
\text { (percent) }\end{array}$ & $\begin{array}{c}\text { Aspect } \\
\text { (degree) }\end{array}$ & $\begin{array}{c}\text { Altitude } \\
\text { (meter) }\end{array}$ & $\begin{array}{c}\text { Canopy cover } \\
\text { density } \\
\text { (percent) }\end{array}$ & $\begin{array}{c}\text { Transmission } \\
\text { coefficient } \\
\text { (percent) }\end{array}$ & $\begin{array}{c}\text { Snow } \\
\text { correction } \\
\text { factor }\end{array}$ \\
\hline 1 & 1.1 & 53 & 25 & 2,910 & 18 & 60 & 1.30 \\
2 & 1.0 & 68 & 225 & 2,910 & 18 & 60 & 1.30 \\
3 & 2.9 & 53 & 25 & 2,950 & 5 & 85 & 1.30 \\
4 & 5.8 & 61 & 260 & 3,110 & 10 & 75 & 1.30 \\
5 & 13.7 & 64 & 280 & 3,170 & 40 & 33 & 1.30 \\
& & & & & & & \\
6 & 1.7 & 52 & 260 & 3,170 & 5 & 85 & 1.30 \\
7 & 6.1 & 53 & 55 & 3,050 & 15 & 65 & 1.30 \\
8 & 22.5 & 60 & 15 & 3,050 & 15 & 65 & 1.30 \\
9 & 10.9 & 63 & 245 & 3,050 & 60 & 18 & 1.30 \\
10 & 2.7 & 26 & 28 & 2,930 & 10 & 75 & 1.30 \\
& & & & & & & \\
11 & 0.7 & 57 & 275 & 2,930 & 10 & 75 & 1.30 \\
12 & 12.1 & 52 & 260 & 3,255 & 10 & 75 & 1.30 \\
13 & 3.8 & 53 & 55 & 3,230 & 10 & 75 & 1.30 \\
14 & 7.6 & 57 & 20 & 3,230 & 10 & 75 & 1.30 \\
15 & 0.8 & 15 & 305 & 2,960 & 10 & 75 & 1.30 \\
\hline
\end{tabular}

Generic parameters common to all HRU's:

Maximum daily snowmelt infiltration capacity, SRX

Maximum daily recharge to ground-water reservoir, SEP

Subsurface reservoir routing coefficient, RCF

Ground-water reservoir routing coefficient, $R C B$
$5.08 \mathrm{~cm} / \mathrm{d}$

$0.64 \mathrm{~cm} / \mathrm{d}$

0.0333

0.0058 